

\section{Sumário}

EDITORIAL

Ingo Wolfgang Sarlet, Lilian Rose Lemos Rocha e Patrícia Perrone Campos Mello

1. Direitos Fundamentais, hermenêutica e meio ambiente

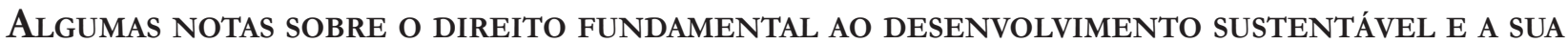
DIMENSÃO SUBJETIVA E OBJETIVA.

Ingo Wolfgang Sarlet e Gabriel de Jesus Tedesco Wedy

El DERECHO HUMANO AL AGUA Y AL SANEAMIENTO.

Belén Burgos Garrido

Até onde VAi o DiReito CONSTITUCIONAL Ao MEIO AMBIENTE ECOlOGICAMENTE EQUILIBRADO? UMA ANÁLISE SOBRE O POSICIONAMENTO BRASILEIRO FRENTE AO NOVO CONSTITUCIONALISMO

LATINO-AMERICANO

Mariana Bruck de Moraes Ponna Schiavetti e Maria Eugênia Bruck de Moraes

El DERECHO HUMANO AL ACCESO A LA INFORMACIÓN AMBIENTAL Y LA JURISPRUDENCIA INTERAMERICANA.

Gonzalo Aguilar Cavallo Garrido

As MÚlTIPLAS DIMENSÕES DO DIREITO FUNDAMENTAL À CIDADE.

Zenildo Bodnar e Priscilla Linhares Albino

Na dúvida EM Favor da natureza? LeVar a sério a Constituição Ecológica na Época do Antropoceno.

Patryck de Araújo Ayala e Mariana Carvalho Victor Coelho

2. Direitos dA NATUREZA................................................................................. 164

A sala de EMERgênCia Ambiental: A PRoteÇão dos direitos da natureza na AmÉrica

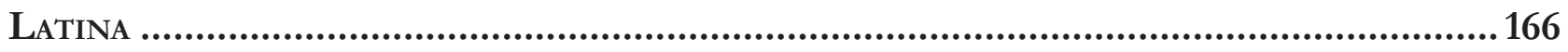

Lilian Rose Lemos Rocha

Procedural theory of THE SubJect of LAW AND NON-HUMan ANimals: CRiteria for RECOGNITION OF LEGAL SUBJECTIVITY FROM THE PERSPECTIVE OF CRITICAL THEORY

Sthéfano Bruno Santos Divino 
Os “ANIMAIS DE PRODUÇÃO” PARA ALIMENTAÇÃO HUMANA E O DIREITO CONSTITUCIONAL AMBIENTAL E ECOLÓGICO: PARADOXOS ÉTICO-JURÍDICOS

Juliane Caravieri Martins e Cicília Araújo Nunes

3. Povos indígenas

Povos Indígenas E PRoteção da NATUREZA: A CAMINHO DE UM “GIRO HERMENÊUTICo ECOCÊNTRICO"

Patrícia Perrone Campos Mello e Juan Jorge Faundes Peñafiel

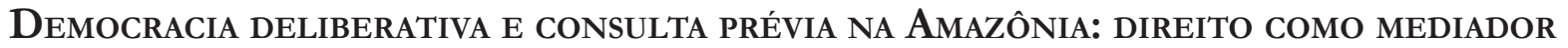

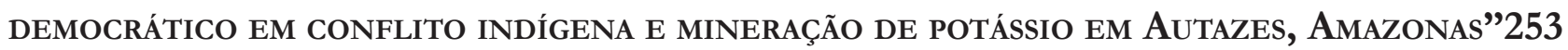
Acursio Ypiranga Benevides Júnior

Rafael da Silva Menezes

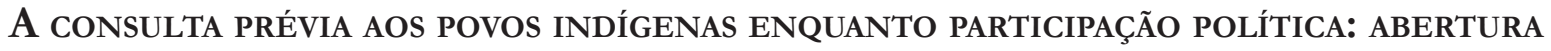
CONSTITUCIONAL BRASILEIRA A ROTAS ALTERNATIVAS DE PROTEÇÃO AMBIENTAL.

Laura Fernanda Melo Nascimento e Adriano Fernandes Ferreira

4. ECOFEMINISMO

MEIO AMbIENTE, CUIDADo E DIREITO: INTERSECÇÕES TEÓRICAS E PRÁTICAS DESDE A DIALÉTICA DA DIFERENÇA 294

Gustavo Seferian e Carol Matias Brasileiro

ECOFEMINISMO INTERSECCIONAL E DECOLONIAL NO DIREITO BRASILEIRO: A NOVA POLÍTICA estadual de SEgurança de barRagens de Minas Gerais.

Émilien Vilas Boas Reis e Vanessa Lemgruber

\section{INSTRUMENTOS E INCENTIVOS PARA A CONCRETIZAÇÃO DA PROTEÇÃO AO MEIO} AMBIENTE

STARTUP E O DESAFIO DO COMPLIANCE

Grace Ladeira Garbaccio, Alexandra Aragão, Vanessa Morato Resende e Ana Walêska Xavier Araújo

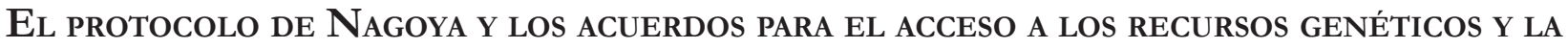
PARTICIPACIÓN JUSTA Y EQUITATIVA EN LOS BENEFICIOS QUE SE DERIVEN DE SU UTILIZACIÓN: UNA PROPUESTA DISCUTIDA

Roberto Concha Machuca

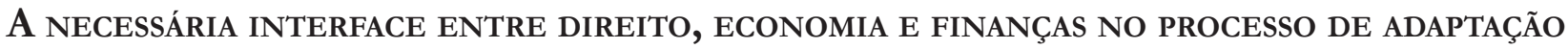
Às MUDANÇAS CLIMÁTICAS 363

Fernanda Dalla Libera Damacena 
RELEVÂNCIA E ESTRATÉGIAS PARA VIABILIZAÇÃo DA CRIAÇÃO DE CORREDORES ECOLÓGICOS EM Área da Mata Atrântica setentrional

Juliana Garcia Vidal Rodrigues, Sueli Aparecida Moreira e Eliza Maria Xavier Freire

AgrotóXICOS, DOMINAÇÃO E FRONTEIRAS: SIGNIFICAÇÃO, RELAÇÃO E PERSPECTIVAS SOBRE O PACOTE TECNOLÓGICO AGRÍCOLA E A AMAZÔNIA BRASILEIRA 418

Giovanni Martins de Araújo Mascarenhas, José Antônio Tietzmann e Silva e Luciane Martins de Araújo

SERÁ O SANEAMENTO BÁSICO UMA ESPÉCIE DE SERVIÇO PÚBLICO DE INTERESSE LOCAL? UM ESTUDO À LUZ DA TEORIA DAS CAPACIDADES ESTATAIS APLICADA AOS MUNICÍPIOS BRASILEIROS.. 440 Thaís de Bessa Gontijo de Oliveira e Fabiana de Menezes Soares

IMPASSES DA ADOÇÃO DA TÉCNICA DE DESSALINIZAÇÃO: BENEFÍCIOS PARA A SAÚDE PÚBLICA E DANOS PARA O MEIO AMBIENTE.

Ivone Rosana Fedel, André Studart Leitão e Gerardo Clésio Maia Arruda

As CONTRATAÇõES PÚBliCAS SUSTENTÁVEIS E A IMPLEMENTAÇão DA META 12.7 DOS OBJETIVOS PARA O DESENVOLVIMENTO SUSTENTÁVEL (ODS) NO BRASIL: AVANÇOS E RETROCESSOS .492 Lucas Campos Jereissati e Álisson José Maia Melo

6. Acesso À justiça em matéria AMbiental.

Desafíos del acceso a la justicia Ambiental en Chile. Jairo Enrique Lucero Pantoja, Gonzalo Aguilar Cavallo e Cristian Contreras Rojas

CONSIDERAÇÕES SOBRE A PARTICIPAÇÃO JUDICIAL DIRETA EM DEFESA DO MEIO AMBIENTE NO Brasil, No Equador e na Bolívia . .556 Leonardo Leite Nascimento e Valmir César Pozzetti

JURISDIÇÃo CONSTITUCIONAL E PATRIMÔNIO CULTURAL: UM ESTUdO DE CASO DA ADPF 206.575 Almir Megali Neto, Flávio Couto Bernardes e Pedro Augusto Costa Gontijo

A TESE DE IMPRESCRITIBILIDADE DE DANOS AMBIENTAIS EM REPERCUSSÃO GERAL DO SUPREMO TRIBUNAL FEDERAL E A POSSIBILIDADE DE APLICAÇÃO DA TEORIA DO RISCO AGRAVADO............602 Vicente de Paulo Augusto de Oliveira Júnior e Daniel Pagliuca

7. Mudanças Climáticas.

Agenda 2030: EMERgênCIA CLIMÁtiCa E O PAPEL DAS INSTITUIÇões PÚBLICAS .624 Luiz Edson Fachin

DÉfis ET PERSPECTIVES POLITIQUES, INSTITUTIONNELles ET NORMATIVES DES AsSEMbléES CITOYENNES: UNE APPROCHE DEPUIS L'EXEMPLE DE LA CONVENTION CITOYENNE SUR LE CLIMAT .636

Benoit Delooz 
Cambio Climático e Inversiones: Esbozando estrategias de armonización para

Andrea Lucas Garí, Jaime Tijmes-Ihl e Johanna Sagner-Tapia

MudANÇAS CLIMÁTICAS E RESPONSABILIDADE CIVIL: UM ESTUDO DE CASO SOBRE A REPARAÇÃo DE

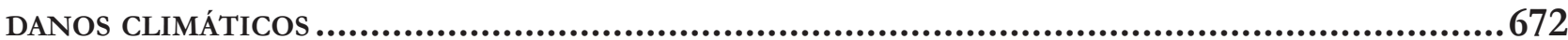

Sabrina Jiukoski da Silva e Thatiane Cristina Fontão Pires 


\title{
Na dúvida em favor da natureza? Levar a sério a Constituição Ecológica na época do Antropoceno*
}

\author{
In doubt when in favor of nature? Taking \\ Ecological Constitution seriously in times of the \\ Anthropocene
}

\author{
Patryck de Araújo Ayala** \\ Mariana Carvalho Victor Coelho***
}

\section{Resumo}

Por meio do método indutivo e de pesquisa bibliográfica e jurisprudencial, este trabalho tem por objetivo justificar e demonstrar que respostas jurídicas que favoreçam a proteção da natureza, na época do Antropoceno, não podem ser o resultado da aplicação de um conteúdo restritivo de um assim denominado princípio in dubio pro natura. Sustenta-se que a fórmula in dubio pro natura não pode ser reduzida a um mandado de, na dúvida se deve proteger a natureza. Argumenta-se que, no lugar de se privilegiar um sentido restritivo para o conteúdo de um princípio in dubio pro natura, é possível ampliá-lo para se justificar decisões pro natura, sempre que se estiver em causa a aplicação de normas ambientais. Para tanto, considera-se, no Direito brasileiro, que as decisões pro natura encontram-se, antes de tudo, estruturadas e bem justificadas em um arranjo institucional a partir do qual não se permite decisões ou o exercício das liberdades econômicas que ultrapasse os limites objetivos da existência dos sistemas naturais (artigo 225, caput, $\ 1^{\circ}$, incisos I e VII, CRFB/88). A proposição é demonstrada pela sua afirmação em um contexto mais alargado de transformação ecológica dos direitos nos tribunais latino-americanos, bem representada não apenas na jurisprudência do Supremo Tribunal Federal (STF) e do Superior Tribunal de Justiça (STJ) brasileiros, referidos neste trabalho, senão na aderência à contribuição que também foi oferecida por tribunais na Argentina, Colômbia, Equador, México, e pela Corte Interamericana de Direitos Humanos (CIDH), por meio de sua Opinião Consultiva (OC) n. 23/2017.

Palavras-Chave: Constituição Ecológica. Integridade Ecológica. Justiça Ecológica. In dubio pro natura. Limites Planetários.

* Recebido em 30/09/2020 Aprovado em 25/01/2021

** Pós-doutor, doutor e mestre em Direito pela Universidade Federal de Santa Catarina. E-mail: pkayala@terra.com.br

*** Mestre em Direito pela Universidade Federal de Mato Grosso.

E-mail: maricvcoelho@hotmail.com

\section{Abstract}

Through the inductive method and bibliographic and jurisprudential research, this work aims to justify and demonstrate that legal responses that favor the protection of nature, at the time of the Anthropocene, cannot be the result of the application of a restrictive content of a so-called in dubio pro natu- 
$r a$ principle. It is argued that the formula in dubio pro natura cannot be reduced to a warrant for when in doubt whether to protect nature. It is argued that, instead of privileging a restrictive sense for the content of a in dubio pro natura principle, it is possible to expand it to justify pro natura decisions, whenever the application of environmental standards is at stake. To that end, it is considered, in Brazilian law, that pro natura decisions are, above all, structured and well justified in an institutional arrangement from which do not allow decisions or the exercise of economic freedoms that exceed the objective limits of the existence of natural systems (article 225, caput, $\mathbb{\Omega} 1$, items I and VII, CRFB / 88). The proposition is demonstrated by its affirmation in a broader context of ecological transformation of rights in Latin American courts, well represented not only in the jurisprudence of the Supreme Federal Court (STF) and the Superior Court of Justice (STJ), referred to in this work, but in adhering to the contribution that was also offered by courts in Argentina, Colombia, Ecuador, Mexico, and by the Inter-American Court of Human Rights (IACHR), through its Advisory Opinion (OC) n. 23/2017.

Keywords: Ecological Constitution. Ecological Integrity. Ecological Justice. In dubio pro natura. Planetary Boundaries.

\section{Introdução.}

A superposição de eventos planetários materializados por uma pandemia global (COVID-19) e a expansão dos efeitos de um estado de emergência gerado pelas mudanças climáticas podem justificar com perfeição, o acolhimento do retrato de um mundo em transformação, ou em metamorfose.

A pandemia e as mudanças climáticas globais sugerem a interpretação de um mundo em transformação distinta de outras que já lhe antecederam, geradas pelo holocausto, o acidente nuclear, o terror e pela globalização.

Nessa interpretação de um mundo em transformação, o estado atual do conhecimento científico permite demonstrar uma importante conclusão, cujo conteúdo é relevante para que possa compreender e justificar o modo como se interpreta o mundo, são realizadas as escolhas e são tomadas as decisões por meio do Direito. No contexto da pandemia planetária e das mudanças climáticas globais, tem origem na ciência a demonstração de que há uma relação de dependência entre a comunidade humana e os sistemas naturais, e o rompimento de determinados processos ecológicos, ou, ainda, o desrespeito de algumas fronteiras estabelecidas nesta relação interespécie (vida humana e não humana) pode originar consequências que se estendem nos dois domínios, humano e não humano.

É assim que consequências pessoais, socioeconômicas e ecológicas são enumeradas e relacionadas pela ciência, relacionadas igualmente à pandemia e às alterações climáticas globais. Deslocamentos ambientais, impacto nos processos produtivos, na segurança alimentar, no sistema sanitário, a proliferação de doenças, o comprometimento de identidades culturais. Da mesma forma, no plano político, assiste-se à expansão da divisão global das sociedades sob a direção de narrativas de resistência ao mesmo conhecimento científico que embasou essas mesmas conclusões.

No plano da relação entre essa realidade e o Direito, assiste-se à confirmação por organismos vinculados à ONU e seus colegiados (especialmente em 2019 e 2020) que monitoram e implementam os tratados e convenções ambientais, que um determinado modelo de enfrentamento dos conflitos ecológicos não foi suficiente para impedir, prevenir e conter essa mesma realidade. Os processos responsáveis pela proliferação de normas ambientais e pela definição de direitos não foram suficientes para obstar o rompimento das relações existentes entre a condição humana e o mundo natural, ou ainda, de diminuir a velocidade de sua degradação. 
Diante de semelhante cenário, é possível explicar, por meio dessa interpretação de um mundo em transformação, que escolhas ou decisões favoráveis à natureza precisam ser estruturadas e justificadas nos sistemas de direitos.

Para o propósito deste trabalho pretende-se justificar que não se pode limitar respostas jurídicas que favoreçam a proteção da natureza como o resultado de uma aplicação privilegiada e restritiva de um, assim denominado, princípio in dubio pro natura. Para tanto, considera-se que respostas jurídicas pro natura podem ser melhor justificadas se for considerada uma transformação e ampliação sobre o conteúdo desse princípio, o qual deve interagir com as conclusões científicas de um mundo em transformação, pelas quais se tem que os sistemas naturais precisam ser respeitados por todas as decisões e escolhas humanas.

O princípio tem expressa previsão no texto da Constituição Equatoriana de 2008 (artigo 395.4) e propõe, como conteúdo, aplicar as disposições que sejam mais favoráveis à natureza, nos casos em que haja dúvida sobre o sentido das normas jurídicas em matéria ambiental.

Por meio desse sentido, as normas jurídicas em matéria ambiental serão aplicadas de forma mais favorável à natureza, nos casos em que existam dívidas sobre seu alcance.

O trabalho faz o uso da experiência de alguns tribunais latino-americanos (especialmente os constitucionais) para demonstrar que o sentido do princípio também pode expressar conteúdo distinto e de maior alcance. Em detrimento de se propor que as normas serão aplicadas em favor da natureza sempre que houver dúvida, propõe-se para seu conteúdo, que o princípio pode ser compreendido como um mandado geral de interpretação e aplicação de normas jurídicas ambientais. Com base nesse ângulo, as normas ambientais sempre deverão ser aplicadas por meio do melhor sentido que favoreça a natureza.

O recente giro ecológico da jurisprudência desses tribunais — nomeadamente na Colômbia, Argentina, México e até mesmo no Brasil — influencia diretamente a pretendida transformação sobre o significado do princípio. Essa transformação resulta dede um contexto no qual é afirmado um conteúdo ecológico para direitos. Por sua vez, a justificação de conteúdos ecológicos para direitos encontra-se assentada na concretização da Constituição, a qual pode chegar em último nível, à afirmação de direitos para a natureza.

De forma distinta de se apresentar uma descrição restritiva, sob a condição de um caminho, e de uma resposta (ecológica), para a solução de estados de dúvida, ou para se justificar que, agora, em contextos de incerteza científica, ou de deficiência sobre o estado da informação disponível, as decisões devem favorecer a natureza, opta-se por explicar sua definição relacionando-o com uma estrutura jurídica que deve favorecer, sempre, respostas em favor da natureza, especialmente quando estiverem presentes cenários de aproximação ou de rompimento dos limites (ou fronteiras) do planeta. Estes (limites planetários) são considerados no trabalho, sob a condição de imperativos de proteção.

É assim que uma abordagem ecológica sobre a concretização da Constituição colabora para se justificar esse conteúdo diferenciado para o princípio e, desse modo, também se permite justificar de forma, de forma mais abrangente, escolhas e decisões pro natura.

Para o fim de desenvolver semelhante proposta, o trabalho se encontra estruturado ao longo de cinco seções.

Inicialmente, nas duas primeiras seções, são caracterizados os cenários de um mundo em transformação, que é definido por um conjunto de assim denominados medos planetários, para o fim de se justificar que os medos planetários também transformam o mundo, no modo de sua organização política e social. São priorizados dois medos planetários (as mudanças climáticas e a pandemia planetária), os quais serão situados no contexto de uma assim denominada época do Antropoceno, para o fim de se demonstrar que os medos também transformam o modo de interpretar o mundo, sob as mais distintas perspectivas. Naquilo que diz respeito a este trabalho, interessa demonstrar que os medos planetários transformam o modo de interpretar o mundo, a partir do momento em que se permite justificar, definitivamente, por meio das conclusões cien- 
tíficas extraídas do contexto da pandemia e das mudanças climáticas globais, que: a) a comunidade humana depende dos sistemas naturais e que, b) não há mais espaço para o acolhimento institucional de relações de instrumentalização humana da vida, independente de juirzos imperativos sobre limites.

É desse modo que as duas primeiras seções priorizarão a afirmação de uma posição relevante assumida pelas conclusões científicas sobre mudanças climáticas e pandemia para se demonstrar, em seguida, que essas conclusões se encontram materializadas em três definições de ciência climática: os limites planetários, pontos de inflexão e o espaço operacional seguro.

Sustenta-se na terceira seção que os sistemas jurídicos precisam respeitar os limites da natureza e as leis da natureza e, sob semelhante abordagem, demonstra-se que é possível uma aproximação entre Direito e sistemas naturais por meio da ordem constitucional brasileira. Argumenta-se que o texto do artigo $225, \Omega 1^{\circ}$, inciso I e VII, especialmente, da Constituição Brasileira, propõe deveres de proteção cujo conteúdo veicula, objetivamente, imperativos de não se violar os limites planetários, e de se respeitar a integridade dos processos ecológicos e dos sistemas naturais, sob o acolhimento de uma constituição ecologicamente sensível. Sob essa perspectiva sustenta-se que já seria possível respostas jurídicas pro natura sob uma direção ampliativa.

Assim, considera-se na seção seguinte, que a justificação de uma abordagem ecológica de direitos e dos sistemas de direitos passa, antes de tudo, por levar a sério a Constituição, e levar a sério um modelo de Constituição, aquela que descreve, objetivamente, compromissos com a natureza, com os sistemas naturais, e com os processos ecológicos e sua integridade.

As duas últimas seções se ocuparão de desenvolver um sentido para o princípio in dubio pro natura, propondo para este uma realidade de conexão e de coerência com a já sobredita abordagem ecológica de direitos.

A partir de uma consideração sobre a jurisprudência selecionada de casos nacionais, no Supremo Tribunal Federal (STF), no Superior Tribunal de Justiça (STJ), e de alguns casos extraídos da jurisprudência latino-americana (Colômbia, Equador e México), pretende-se demonstrar que se, neste momento, de emergência para uma virada ecológica de direitos, é necessário justificar adequadamente modelos de decisão que favoreçam a natureza, o conteúdo de um princípio in dubio pro natura deve ser compreendido em contexto ampliado, para além de instrumento para se favorecer a natureza na hipótese de dúvida.

Considera-se que um imperativo pro natura, nos sistemas de direitos, não pode ser restritivamente justificado no resultado de escolhas que sejam realizadas apenas em contextos de dúvida (in dubio pro natura). Para além da dúvida, sustenta-se que o estado atual do conhecimento científico disponível já permite explicar uma proteção pro natura, sempre que se tiver de considerar escolhas ou decisões sobre a intervenção que ameace qualquer dos limites planetários, como, v.g, a (perda da) diversidade biológica.

A jurisprudência dos tribunais latino-americanos selecionada neste trabalho demonstra que a recente afirmação em suas decisões, de direitos da natureza, e de uma abordagem ecológica para direitos nas Constituições, traduzem não apenas um giro ecológico em sua jurisprudência. Sustenta-se que, no âmbito desse giro ecológico, podem estar as melhores oportunidades para se favorecer, justamente, a ampliação para o seu conteúdo. No lugar de se justificar escolhas pro natura em casos de dúvida, jurisprudência desses tribunais, neste momento, permite justificar que todas as normas ambientais devem ser aplicadas com o sentido que melhor favoreça a natureza.

Portanto, nesse sentido, considera-se que, para além da dívida, um imperativo de proteção da natureza surge de uma abordagem ecológica para direitos. Semelhante virada ecológica de direitos encontra-se em curso no âmbito da jurisprudência dos tribunais nacionais latino-americanos e da Corte Interamericana de Direitos Humanos (CIDH), após o pronunciamento na OC n. 23/2017. 


\section{0 antropoceno e a ciência do sistema terrestre}

$\mathrm{Na}$ época geológica compreendida como Antropoceno, os sistemas ecológicos ficaram mais vulneráveis. Se é uma época jovem (Antropoceno), não é possível saber como lidar com os impactos que serão trazidos ${ }^{1}$, inclusive, para a regulação jurídica, aspecto que suscita indagações sobre a utilidade do próprio Direito em uma época geológica que foi iniciada pelas intervenções do próprio homem e pelas transformações que este submeteu a natureza e os processos ecológicos.

A humanidade transformou uma época geológica e fragilizou os sistemas ecológicos. ${ }^{2} \mathrm{O}$ homem seria o único causador mas não seria, por outro lado, a única vítima das transformações por si infligidas, na medida em que submete todas as demais formas de vida a fragilização de sua integridade. Por essa razão, surge, com evidência, a necessidade de recomposição do valor que se atribui à natureza no contexto da própria comunidade moral.

$\mathrm{Na}$ época do Antropoceno as medidas de proteção que priorizem as demandas dos humanos sem considerar a necessidade de se respeitar a integridade dos sistemas terrestres são medidas limitadas e incapazes de assegurar a proteção necessária perante os riscos aos processos ecológicos que sustentam todas as formas de vida.

A constatação da realidade das ameaças dessa época geológica — afirmada por Paul Crutzen ${ }^{3}$ — influencia, diretamente, o modo como um dos principais instrumentos jurídicos que identifica aquela racionalidade antropocêntrica, deve se comportar em contextos onde imperativos ecológicos não mais podem ser ignorados pelas escolhas públicas e privadas.

Se a consideração de uma nova época geológica nos permite estabelecer ao menos um juízo consensual ou de certeza, este seria o de que este é um mundo em transformação, sendo relevante neste trabalho, que se possa compreender e interpretar esse mundo em transformação, por meio do Direito.

Em sua sociologia do risco, Ulrich Beck propôs interpretar um mundo em transformação designando-lhe um estado de metamorfose, o qual teria origem em um movimento produzido pelo evento mudanças climáticas, evento este que poderia suscitar oportunidades de emancipação ${ }^{4}$.

Esse mesmo mundo pode ser interpretado de formas distintas. Edgar Morin destaca uma trindade inspirada na teologia cristã, e baseada no Espírito Santo, no Pai e no Filho, que foi sucedida por uma trindade que tende a guiar a interpretação deste mundo, sob a condição dos valores da humanidade. Ela seria baseada na trindade liberdade, igualdade e fraternidade. ${ }^{5}$

A humanidade como se conhece a partir das revoluções liberais burguesas, guia-se por uma trindade característica e que é diferente. Ela é caracterizada pela liberdade, pela igualdade e pela fraternidade, sendo que esta última não pode ser imposta. Ela precisa ter origem na organização coletiva dos sujeitos e só existe quando e a partir do momento em que nos entendermos e nos respeitarmos ${ }^{6}$. Respeitar o outro é um passo para respeitar coletividades (sujeitos) e por fim, respeitar o comum (valores).

\footnotetext{
CRUTZEN, Paul Josef. The Anthropocene: conceptual and historical perspectives. Philosophical Transactions of The Royal Society A Mathematical Physical and Engineering Sciences, n.369, p. 847-849, 2011. HAMILTON, Clive. Defiant Earth. The fate of humans in the anthropocene. Cambridge: Polity, 2017. p. 7.

2 HAMILTON, Clive. Defiant Earth. The fate of humans in the anthropocene. Cambridge: Polity, 2017. p. 5.

3 CRUTZEN, Paul; STEFFEN, Will; MACNEILL, John. The Anthropocene: Are Humans Now Overwhelming the Great Forces of Nature? Ambio, v. 36, n. 8, p. 613-621, Dec. 2007; CRUTZEN, Paul. Human Impact On Climate Has Made This the "Anthropocene Age". New Perspectivies Quartely, v. 22, n. 2, p. 14-16, Mar. 2015; CRUTZEN, Paul. STEFFEN, Will; MACNEILL, John; GRINEVALD, Jacques. The Anthropocene: conceptual and Hisorical Perspectives. Philosofical Transactions of the Royal Society, v. 369, p. 842-867, 2011.

4 BECK, Ulrich. A metamorfose do mundo. Como as alterações climáticas estão transformando a sociedade. Lisboa: Edições 70, 2017. p. 150.

MORIN, Edgar. Fraternidade. Para resistir à crueldade do mundo. São Paulo: Palas Atenas, 2019.p. 11-13.

6 MORIN, Edgar. Fraternidade. Para resistir à crueldade do mundo. São Paulo: Palas Atenas, 2019. p. 12-13.
} 
Há um mundo em transformação social, econômica, cultural, religiosa, ecológica, mundo que estabeleceu uma comunidade de destino e uma comunidade de riscos. Estabelecem-se, de algum modo, conexões, ainda que parciais, com o global, e dificilmente com o local. O desafio proposto neste mundo em transformação é a compreensão entre os povos e a emergência de uma fraternidade planetária ${ }^{7}$. Para Edgar Morin, a Pátria é a Terra-Pátria, é a comunidade de destino de todos os seres humanos do planeta ${ }^{8}$, e este destino foi desafiado, neste momento, por dois medos globais ou planetários, a saber: a pandemia virótica e as mudanças globais, os quais se encontram estabelecidos simultaneamente.

Já não é novo se pensar que o modo como se vive, como se compreende o mundo e como se pode explicá-lo agora e após um cenário de pandemia, mudou e mudará substancialmente.

Não é apenas a proliferação de efeitos objetivos nos planos econômico e social que se pode enfatizar. As economias foram e serão afetadas, as nações ficarão mais pobres, as políticas públicas serão financeiramente afetadas, as pessoas ficarão mais vulneráveis.

Se o mundo efetivamente parou em um primeiro momento, com as execuções de medidas de lockdown em escala global, como Sousa Santos explicou, nós deveremos ter condições de aprender algumas lições nesta pausa do mundo9. Entre essas lições, estão algumas que interessam particularmente o desenvolvimento deste texto, as lições oferecidas pelo estado do conhecimento científico disponível.

A União Europeia ${ }^{10}$ já havia sinalizado mesmo antes de um mundo em pandemia, que o caminho, e agora a reconstrução desse mundo, deveria ser baseada em relações econômicas que proponham relações mais responsáveis com a natureza, colaborando para o fortalecimento de uma tendência pré-pandemia que já se vinha fortalecendo na esteira da divulgação científica do $5^{\circ}$ relatório do IPCC: um green new deal, na linha do que sustenta Naomi Klein ${ }^{11}$.

A pandemia agrega-se a um segundo medo planetário ou global que já se encontrava em curso, a saber, as mudanças climáticas. Ambas aumentam a visibilidade sobre a transformação do modo como os problemas devem ser compreendidos pelas pessoas e pelas instituições, e propõem ao menos um aprendizado comum: as lições que podem ser oferecidas e acolhidas a partir da ciência para o fim de se demonstrar a existência de uma relação de dependência entre as ações humanas e os sistemas naturais.

É assim que, por meio da pandemia global em curso, se permitiu evidenciar, por meio da ciência, que $75 \%$ das últimas doenças infecciosas conhecidas nas três últimas décadas possuem origem zoonótica ${ }^{12}$.

A perda de qualidade dos recursos naturais produz consequências sobre extenso conjunto de direitos humanos ${ }^{13}$, e a relação entre a intervenção humana e realidades ecológicas disruptivas com consequências de grande magnitude já não se encontram fora do alcance da cognição científica ${ }^{14}$.

Já se foi possível observar, v.g, que o período de redução da ação humana permitiu que os primeiros

\footnotetext{
MORIN, Edgar. Fraternidade. Para resistir à crueldade do mundo. São Paulo: Palas Atenas, 2019. p. 41.

MORIN, Edgar; KERN, Anne Brigitte. Terra-pátria. Porto Alegre: Sulina, 2005. p. 176-177.

SOUSA SANTOS, Boaventura de. A Cruel Pedagogia do Virus. Coimbra: Almedina, 20020. p. 22-28.

10 EUROPE. European Comission. COMMUNICATION FROM THE COMMISSION TO THE EUROPEAN PARLIAMENT, THE EUROPEAN COUNCIL, THE COUNCIL, THE EUROPEAN ECONOMIC AND SOCIAL COMMITTEE AND THE COMMITTEE OF THE REGIONS. The European Green Deal Disponível em: <https://ec.europa.eu/info/sites/ info/files/european-green-deal-communication_en.pdf> Acesso em: 14 jul. 2020.

11 KLEIN, Naomi. The Burning Case for a Green New Deal. New York: Simon \& Schuster. 2019.

12 WORLD HEALTH ORGANIZATION. Zoonotic disease: emerging public health threats in the Region. Disponível em: <http://www.emro.who.int/fr/about-who/rc61/zoonotic-diseases.html> Acesso: 15 jul. 2020.

13 UNITED NATIONS. General Assembly. Report of the Special Rapporteur on the issue of human rights obligations relating to the enjoyment of a safe, clean, healthy and sustainable environment, David R. Boyd. Human rights depend on a healthy biosphere. Disponível em: <https://undocs.org/A/75/161> . Acesso em: 10 set. 2020.

14 Cf. ROBINSON, Nicholas A.; WALZER, Christian. How Do We Prevent the Next Outbreak? Our planning needs to take account of the complex interconnections among species, ecosystems and human society. Disponível em: <https://blogs.scientificamerican. com/observations/how-do-we-prevent-the-next-outbreak/>. Acesso em: 15 set. 2020.
} 
números comparativos dessa relação pudessem ser empiricamente colhidos e utilizados para escolhas e processos de decisão ${ }^{15}$.

Da mesma forma também se permitiu propor que a diminuição do desflorestamento poderia contribuir para o controle biológico, dados os números já ilustrados pela OMS, dos efeitos dessa relação nociva entre práticas extrativistas e natureza. ${ }^{16}$

Em 2010 o mundo se comprometeu com 10 metas para salvar o mundo (Metas de Aichi) que deveriam ser atingidas em $2020^{17}$.

Em 15 de setembro de 2020, o Secretariado da Convenção da Diversidade Biológica (CDB) divulgou seu relatório final para o fim de consideração do estado de implementação das metas de Aichi, no qual se concluiu não terem sido atingidas nenhuma das metas por nenhuma das nações ${ }^{18}$.

No mesmo contexto, o Clube de Roma apresentou dois planos de emergência climática ${ }^{19}$. Se as metas falharam e eram metas estruturantes, convergentes com a formação de um green new deal, deve-se compreender que essas metas deixaram de ser metas de longo praz̧o.

Por isso, neste momento, as gerações presentes já são tão importantes quanto as futuras gerações foram no passado, as quais deixaram de ser beneficiárias prioritárias em uma narrativa/argumento de proteção útil ou viável.

Sempre, pela narrativa do Direito ambiental, até o momento ${ }^{20}$, e é possível constatar isso na narrativa dos instrumentos internacionais, políticas e na literatura, os beneficiários prioritários das narrativas e dos discursos sempre foram as futuras gerações, e sua conexão com o meio ambiente. Nesse momento, pelo estado do conhecimento científico que se produz agora, as presentes gerações também são importantes, e tão importantes quanto são as futuras gerações e, especialmente, os sistemas naturais.

Corine Pelluchon alertou, em recente entrevista, que a pandemia nos exigiu refletir de forma radical sobre a relação humana para com a vida não humana ${ }^{21}$. Ela impôs o levantamento das hierarquias existentes entre os mundos humano e não humano, mas também enfatizou as fronteiras biológicas existentes entre ambos, alertando não ser possível a instrumentalização da vida sem que se sofra consequências dessas ações $^{22}$. A pandemia virótica global ilustra de uma forma bastante clara que essas fronteiras hierárquicas foram rompidas e também produziram consequências.

O vírus atravessou fronteiras interespécies e nessa relação o homem é o sujeito mais frágil. Por fim, e este é o argumento de relevância para o desenvolvimento desta seção, a pandemia levantou as hierarquias e devolven o mundo (reparon o mundo) ao seu estado anterior, exigindo que a natureza seja apenas a natureza, e não

15 RUTZ, Christian et al. COVID-19 lockdown allows researchers to quantify the effects of human activity on wildlife. Nature Ecology \& Evolution, v. 4, p. 1156-1159, sept. 2020.

16 TOLEFFSON, Jeff. Why Deforestation and Extinctions make Pandemics More Likely. Nature, v. 584, p. 175-16, aug. 2020.

17 CONVENTION ON BIOLOGICAL DIVERSITY. Aichi Biodiversity Targets. Disponível em: < https://www.cbd.int/sp/targets/>. Acesso em 15 jul. 2020.

18 UNITED NATIONS ENVIRONMENTAL PROGRAMME. Convention on Biological Diversity. Global Biodiversity Outlook 5. Disponível em: <https://www.cbd.int/gbo5>. Acesso em: 20 set. 2020.

19 PLANETARY EMERGENCY PLAN: Securing a New Deal for People, Nature and Climate. Switzerland: The Clube of Rome, 2019. PLANETARY EMERGENCY 2.0: Securing a New Deal for People, Nature and Climate. Switzerland: The Clube of Rome, 2020.

20 Por todos os argumentos, restringe-se a registrar seu expresso reconhecimento nos textos de 1972 e de 1992 nas respectivas Cúpulas do Meio Ambiente e Desenvolvimento.

21 PELLUCHON, Corine. El coronavirus nos muestra vulnerables, pero puede traer una toma de conciencia. 2020. Disponível em: < https:// www.clarin.com/revista-enie/ideas/corine-pelluchon-coronavirus-muestra-vulnerables-puede-traer-toma-conciencia-_0_h5o9qiPvD.html > Acesso em: 15 jul. 2020. Para a compreensão completa sobre a definição de reparar o mundo, conferir: PELLUCHON, Corine. Réparons le monde. Humains, animaux, nature. Paris: Payot \& Rivage, 2020.

22 PELLUCHON, Corine. El coronavirus nos muestra vulnerables, pero puede traer una toma de conciencia. 2020. Disponível em: <https:// www.clarin.com/revista-enie/ideas/corine-pelluchon-coronavirus-muestra-vulnerables-puede-traer-toma-conciencia-_0_h5o9qiPvD.html > Acesso em: 15 jul. 2020. 
um objeto de instrumentalização no interesse de utilidades humanas. ${ }^{23}$

Os grandes medos planetários descritos por Ulrich Beck em sua sociologia do risco (o acidente nuclear, o terror e a mudança climática) poderiam ser complementados ainda, com um que lhes antecedeu, o holocausto (que foi o precursor e o motor do modo contemporâneo como são definidos direitos humanos), e um que the sucedeu, a pandemia. São cinco, portanto, os medos globais, estando dois deles, a pandemia e a mudança climática, simultaneamente em curso, neste momento.

Uma segunda lição é também ofertada pelos medos globais e planetários. Se a primeira nos indica a dependência da comunidade humana e os sistemas naturais, a segunda nos informa, por meio do relatório de 2020, para a Convenção sobre a Diversidade Biológica (CDB $)^{24}$, e do relatório do Programa das Nações Unidas para o Meio Ambiente (PNUMA) sobre o Estado de Direito Ambiental, de 2019²5, que a comunidade humana aprendeu muito pouco até o momento, pois os danos aumentaram e nossa fragilidade também continuou aumentando, estando exposta por meio do último medo global, a pandemia.

Logo, se tornou visível que as estratégias que não romperam com um modelo de instrumentalização da natureza falharam - portanto, aprendemos pouco - e que devemos reconhecer, de forma imperativa, a existência da relação de dependência da comunidade humana perante os sistemas naturais, como parte de uma nova estratégia de ação, e de compromissos para com a natureza.

A próxima seção desenvolverá de que modo se encontra disponível uma oportunidade de aprendizagem do Direito, por meio da Ciência do Sistema Terrestre, no interesse da proteção jurídica da natureza.

\section{A ciência do sistema terrestre a serviço da proteção jurídica da natureza}

Na data de 22 de setembro de 2020, Carlos Nobre apresentou em audiência pública convocada no âmbito do julgamento da Arguição de Descumprimento de Preceito Fundamental (ADPF) n. $708^{26}$, o resultado de estudos por si realizados, em conjunto com James Lovejoy nos anos de 2018 e $2019^{27}$. Nestes estudos foi possível demonstrar resultados que já permitiriam afirmar a existência de um tipping point (um ponto de não retorno, ou ponto de inflexão $)^{28}$ para o bioma amazônico. Nesses estudos se concluiu que a superação de $20 \%$ de desmatamento do bioma já conduziria a um processo de savanização sem retorno. Esse seria o estado de irreversibilidade, o qual não permitiria, nem mesmo em milhares de anos, restaurar o mesmo nível de diversidade biológica original. Advertiu na mesma ocasião, que já teria sido atingido o índice de $17 \%$ de desmatamento, já se aproximando, portanto, de um perigoso tipping point ${ }^{2}$.

23 PELLUCHON, Corine. El coronavirus nos muestra vulnerables, pero puede traer una toma de conciencia. 2020. Disponível em: <https:// www.clarin.com/revista-enie/ideas/corine-pelluchon-coronavirus-muestra-vulnerables-puede-traer-toma-conciencia-_0_h5o9qiPvD.html> Acesso em: 15 jul. 2020

24 UNITED NATIONS ENVIRONMENTAL PROGRAMME. Convention on Biological Diversity. Global Biodiversity Outlook 5. Disponível em: <https://www.cbd.int/gbo5>. Acesso em: 20 set. 2020.

25 UNITED NATIONS ENVIRONMENTAL PROGRAMME. Environmental Rule of Law. First Global Report. 2019. Disponível em: <https://www.unenvironment.org/resources/assessment/environmental-rule-law-first-global-report> Acesso em: 15 jul. 2020.

26 BRASIL. Supremo Tribunal Federal. Audiodescrição. Audiências Públicas do STF - Fundo do Clima - 4ª Parte. Disponível em: $<$ https://www.youtube.com/watch?v=uK5hNV-NDY0>.Acesso em: 25 set. 2020.

27 NOBRE, Carlos; LOVEJOY, James. Amazon Tipping Point. Science Advances, Issue 4, p. 1, Feb. 2018; NOBRE, Carlos; LOVEJOY, James. Amazon tipping point: Last chance for action. Science Advances, Issue 5, p. 1-2, Dec. 2019.

28 De acordo com Timothy Lenton (Et. al): "The term "tipping point" commonly refers to a critical threshold at which a tiny perturbation can qualitatively alter the state or development of a system.”. (LENTON, Timothy M.; HELD, Hermann; KRIEGLER, Elmar Et. al. Tipping elements in the Earth's climate system. PNAS, 2008. Disponível em: < https://www.pnas.org/content/105/6/1786> Acesso em: 30 out. 2020).

29 BRASIL. Supremo Tribunal Federal. Audiodescrição. Audiências Públicas do STF, Fundo do Clima, $4^{\text {a }}$ Parte. Disponível em: 
Essa amostra de produção científica, no domínio da ciência climática, permite que se estruture o argumento central neste trabalho, para justificar uma abordagem ecológica dos direitos: por meio da ciência, neste momento, é que se permite demonstrar a relação de dependência da comunidade humana em relação aos sistemas naturais e processos ecológicos.

Para se fazer o uso da imagem proposta por Corine Pelluchon, de reparação do mundo, é a ciência que, neste momento, pode ser útil e pode colaborar para reparar o mundo. É ela quem pode ser útil e pode colaborar para devolver a natureza ao seu lugar (de natureza), e que pode colaborar para se justificar argumentos para levantar as hierarquias construídas socialmente entre humanos e o mundo natural.

A pandemia virótica planetária tornou essa realidade de dependência ainda mais evidente e, mais uma vez, é a ciência quem confirmou tal realidade, demonstrando-se que as pandemias conhecidas são majoritariamente zoonóticas.

Por outro lado, é por meio da ciência, e de ciência climática, que se faz possível demonstrar essa dependência por meio de conceitos como os de espaço operacional seguro, limites ou fronteiras planetárias, ou ainda, o de pontos de inflexão (pontos de não retorno, tipping points).

A noção da ciência para a normatividade do direito deve servir para o fim de relacionar a necessidade desse cenário de dependência com a necessidade de se compreender o que é e o que deve ser, de fato, a proteção jurídica da natureza e dos sistemas terrestres.

Isso somente poderá ser alcançado, em primeiro lugar, se o Direito deixar de ignorar as leis da natureza. Transportar essa necessidade em termos jurídicos sugere que o Direito precisaria, adequadamente, compreender e refletir, em seu processo normativo, a ciência do sistema terrestre, de modo que a natureza passe a ser um valor fundamental para escolhas em que se contextualizem cenários de pontos de inflexão.

A sugestão que se passa a compreender é a de que um Direito que objetive a proteção dos sistemas terrestres deve ser um Direito ecológico, e, para tal, deve ser capaz de entender, corretamente, o que é a natureza $a^{30}$. Entender o que é a natureza levanta a questão quanto ao que se busca proteger, e de que forma é possível se intentar esse objetivo primário de proteção jurídica.

A descrição de uma proposta jurídica que leve a natureza a sério deve se encontrar enquanto integraşão da ciência às normas jurídicas que objetivem a proteção dos sistemas da terra ${ }^{31}$. Sustenta-se que a ciência deve desempenhar importante papel na ecologização de direitos, atuando no e para o direito.

Em primeiro lugar, de modo a corretamente definir o que é natureza, e em segundo lugar, de modo a orientar os processos de tomada de decisões, a fim de que atividades antropogênicas possam respeitar os limites ecológicos dos sistemas terrestres.

A ciência é útil no Direito porque, conforme observa Jan Laitos, a política ambiental, e no presente caso, o direito ambiental, são compreendidos a partir de visões de mundo equivocadas, e que revelam, antes de tudo, que a percepção humana sobre o ambiente natural é fundamentalmente incorreta, visto que baseada

$<$ https://www.youtube.com/watch?v=uK5hNV-NDY0>.Acesso em: 25 set. 2020. O alerta também se encontra consignado em: NOBRE, Carlos; LOVEJOY, James. Amazon tipping point. Last chance for action. Science Advances, Issue 5, p. 1-2, Dec. 2019.

30 Nesse mesmo sentido, afirma Patryck de Araújo Ayala: “(...) O direito precisa entender o que é e o que pode ser a natureza. O que se tem normalmente são normas socialmente instituídas e definidoras do que seja meio ambiente, e que não correspondem à realidade do que é a natureza". (AYALA, Patryck de Araújo. Constitucionalismo global ambiental e os direitos da natureza. In: LEITE, José Rubens Morato; AYALA, Patryck de Araujo; CAPDEVILLE, Fernanda Cavedon; MELO, Melissa Ely; SILVEIRA, Paula Galbiatti; DAROS, Leatrice Faraco. A Ecologização do Direito Ambiental Vigente: Rupturas Necessárias. Rio de Janeiro: Editora Lumen Juris, 2018. p. 150).

31 A necessidade quanto a aproximação da ciência às normas jurídicas de proteção do ambiente pode ser encontrada em: LAITOS, Jan. Why Environmental Policies Fail. Cambridge: Cambridge University Press. 2017; BOTKIN, Daniel B. Adjusting Law to Nature's Discordant Harmonies. Duke Environmental Law and Policy Forum. v. 7:25. 1996; KOTZÉ, Louis J. Global Environmental Constitutionalism in the Anthropocene. Oxford: Hart Publishing, 2016; WESTRA, Laura. The Ethics of Integrity and the Law in Global Governance. University of California, Davis, v. 37:127. 
“(...) não na realidade ou em fatos cientificamente comprovados, mas na falsa suposição e em uma esperança não substanciada" 32 .

O âmbito de um Direito que não protege a natureza porque não enxerga a natureza é favorecido por um cenário em que a compreensão do que se entende por natureza é falsa, irreal, sustentada por suposições do que poderia ser a natureza, e não por compreensões científicas do que realmente consiste a natureza ${ }^{33}$.

Nesse sentido, Jan Laitos observa um estado de incompreensão do Direito ambiental quanto à real percepção do que é natureza, que se manifesta pela existência de "suposições incorretas por de trás das normas ambientais" ${ }^{\prime 3}$.

Um Direito que se pretenda ecológico não pode "[...] transigir com a definição de natureza, a qual se encontra representada pela integridade dos sistemas e dos processos ecológicos" ${ }^{" 35}$.

No Antropoceno, o Direito precisa observar e dialogar com a ciência para enfrentar os problemas de tal época geológica, onde o homem é o responsável por transformações geológicas. O Direito precisa entender o que é e o que pode ser a natureza. O que se tem normalmente são normas socialmente instituídas e definidoras do que seja meio ambiente, e que não correspondem à realidade do que é a natureza.

Conforme explicam Ugo Mattei e Fritjof Capra: “[...] a natureza sustenta a vida por meio de um conjunto de princípios ecológicos que são generativos e não extrativistas." 36

Considerando-se que os desafios propostos para a regulação jurídica da natureza exigem que se afastem as compreensões fundamentalmente equivocadas que os seres humanos detêm sobre os sistemas ecológi$\cos ^{37}$, algumas falsas concepções precisam, portanto, ser superadas, se se deseja falar em um Direito ecológico, ou ecologicamente sensibilizado.

É por meio da correta percepção da natureza que é possível se falar em um Direito ecologicamente sensível ${ }^{38}$, pois há, nesse caso, uma correta consideração relativa à preocupação ecológica em torno dos problemas infligidos aos sistemas ecológicos pelas condutas humanas. A ciência, no direito, portanto, deve auxiliar a correta definição do bem objeto de proteção jurídica em um direito que se diga ecologizado.

De outro modo, a ciência, para o direito, deve atuar de modo a orientar processos de tomada de decisões em contextos de pontos de não retorno. Estudos como o espaço operacional seguro e os limites planetários demonstram que há dependência entre as ações humanas e os sistemas naturais.

Os estudos relativos ao espaço operacional seguro (safe operating system) têm por objetivo identificar e quantificar os limites planetários que não devem ser transgredidos, a fim de evitar que as atividades humanas causem mudanças ambientais inaceitáveis ${ }^{39}$.

O estudo expõe que, se, durante o Holoceno as mudanças ambientais, ocorreram de modo natural e que

32 No original: “(...) based not on reality or scientifically proven fact, but on false assumption and unsubstantiated hope”. (LAITOS, Jan. Why Environmental Policies Fail. Cambridge: Cambridge University Press. 2017. p. 17).

33 LAITOS, Jan. Why Environmental Policies Fail. Cambridge: Cambridge University Press. 2017. p. 17.

34 No original: "Faulty assumptions behind environmental rules". (LAITOS, Jan. Why Environmental Policies Fail. Cambridge: Cambridge University Press. 2017. p. 77).

35 AYALA, Patryck de Araújo. Constitucionalismo global ambiental e os direitos da natureza. In: LEITE, José Rubens Morato; AYALA, Patryck de Araujo; CAPDEVILLE, Fernanda Cavedon; MELO, Melissa Ely; SILVEIRA, Paula Galbiatti; DAROS, Leatrice Faraco. A Ecologização do Direito Ambiental Vigente: Rupturas Necessárias. Rio de Janeiro: Editora Lumen Juris, 2018.149.

36 CAPRA, Fritjof; MATTEI, Ugo. A revolução ecojurídica. O direito sistêmico em sintonia com a natureza e a comunidade. São Paulo: Cultrix, 2018. p. 25.

37 LAITOS, Jan. Why Environmental Policies Fail. Cambridge: Cambridge University Press. 2017. p. 17.

38 A noção de sensibilidade ecológica (ecological sensitivity) é utilizada por Oren Perez e será abordada na seção 3 do presente trabalho (PEREZ, Oren. Ecological Sensitivity and Global Legal Pluralism: Rethinking the Trade and Environment Conflict. Oxford: Hart Publishing, 2004).

39 ROCKSTROM, Johan; STEFFEN, Will; NOONE, Kevin; Et al. A safe operating space for humanity. Nature. v. 461/24, 2009. Disponível em: <https://www.nature.com/articles/461472a> Acesso em: 20 set. 2020. 
a capacidade regulatória dos sistemas terrestres foi capaz de manter as condições físicas que habilitam o desenvolvimento humano, a nova era do Antropoceno revela que as atividades humanas podem desestabilizar, criticamente, os sistemas biofísicos e desencadear mudanças ambientais abruptas ou irreversíveis, que podem ser deletérias ou mesmo catastróficas para o bem estar humano ${ }^{40}$.

Em sua grande parte, em razão de uma crescente dependência do uso de combustíveis fósseis e formas industrializadas de agricultura, as atividades humanas no Antropoceno atingiram um nível que pode danificar os sistemas que mantêm a vida da Terra ${ }^{41}$.

De igual modo, os estudos relativos aos limites planetários indicam que há uma necessidade urgente de um novo paradigma que integre o desenvolvimento contínuo das sociedades humanas e a manutenção do Sistema Terrestre em um estado resiliente ${ }^{42}$. Johan Rockstrom, Will Steffen et al. explicam que a estrutura da fronteira planetária contribui para tal paradigma ao fornecer uma análise baseada na ciência, do risco de que as perturbações humanas desestabilizem o Sistema Terrestre na escala planetária.

Os autores defendem que um limite planetário conforme originalmente definido não é equivalente a um limite global ou ponto de inflexão. Assim, o limite planetário proposto não é colocado na posição do limite biofísico, mas sim a montante dele ${ }^{43}$.

A noção dos estudos científicos no direito ambiental é apontada por Ingo Sarlet e Tiago Fensterseifer em específico em relação aos limites planetários - como parâmetro para a progressividade das leis dos homens de proteção ecológica em face da força imperativa das leis da naturez̧a no Antropoceno ${ }^{44}$.

\section{Afirmam que:}

(...) os limites normativos colocados pelo Direito à ação humana - por exemplo, ao estabelecer o regime jurídico de proteção ecológica — devem dialogar necessariamente com os limites naturais ou ecológicos, reconhecendo-se, como comprovado cientificamente, que muitos dos denominados 'limites ou fronteiras planetárias' já foram ultrapassados (...).

Os limites normativos de regulação para o direito ambiental devem estar, necessariamente, vinculados aos limites estabelecidos e determinados pelas ciências dos sistemas terrestres.

Enquanto a proteção da natureza esteja fundamentada em acepções falsas ou ilusórias, não é possível que a estrutura jurídica para o enfrentamento dos problemas ecológicos — na qualidade de uma teoria antropocêntrica e que se fundamenta em definições que distorcem a noção de realidade ecológica — ofereça respostas a níveis satisfatórios de proteção dos sistemas terrestres.

Nessa perspectiva, o compromisso com uma proteção verdadeira da natureza poderá ser alcançado não apenas por meio do real enfrentamento da extensão e dos motivos da crise ambiental acentuada pelo Antropoceno, senão também pelo fortalecimento da ciência do sistema terrestre através do direito.

É por meio da mesma ciência climática que se permite justificar e explicar porque é, agora, imperativo e é uma emergência, respeitar e proteger mais do que utilidades humanas, respeitar e proteger os próprios sistemas naturais, afastando-os de seus tipping points ${ }^{45}$.

\footnotetext{
40 ROCKSTROM, Johan; STEFFEN, Will; NOONE, Kevin; Et al. Planetary boundaries: exploring the Safe Operating System for Humanity. Ecology and Society. v. 14. 2009. Disponível em: < https://www.jstor.org/stable/26268316?seq=2\#metadata_info_tab_contents> Acesso em: 21 set. 2020.

41 ROCKSTROM, Johan; STEFFEN, Will; NOONE, Kevin; Et al. A safe operating space for humanity. Nature. 2009.

42 STEFFEN, Will; RICHARDSON, Katherine; ROCKSTROM, Johan; Et al. Planetary boundaries: Guiding buman development on a changing planet. Science, v. 347. 2015. Disponível em: < https://science.sciencemag.org/content/347/6223/1259855> Acesso em: 21 set. 2020.

43 STEFFEN, Will; RICHARDSON, Katherine; ROCKSTROM, Johan; Et al. Planetary boundaries: Guiding buman development on a changing planet. 2015.

44 SARLET, Ingo Wolfgang; FENSTERSEIFER, Tiago. Direito constitucional ecológico: constituição, direitos fundamentais e proteção da natureza. 6. ed. São Paulo: Thomson Reuters Brasil, 2019. p. 384.

45 LENTON, Timothy M.; HELD, Hermann; KRIEGLER, Elmar Et. al. Tipping elements in the Earth's climate system. PNAS, 2008.
} 
Com essa estrutura de definição e interpretação da realidade por meio da ciência climática, é possível, neste momento, reforçar a mesma premissa esboçada na seção anterior, agora orientada para lhe extrair consequências, a saber, para uma abordagem ecológica dos direitos: por meio da ciência (climática) é permitido demonstrar que uma relação de dependência da comunidade humana em relação aos sistemas naturais e processos ecológicos, existe.

Está se propondo, portanto, que uma forma de justificar a existência de uma abordagem ecológica dos direitos é baseada em ciência. Nessa linha de argumentação (e demonstração), sustenta-se com ciência (climática), que a dependência entre a comunidade humana e os sistemas naturais é uma realidade.

É a ciência que está colaborando com instrumentos para reparar o mundo no contexto das mudanças climáticas e da pandemia. É por meio dela que se podem obter caminhos para se justificar devolver a natureza ao seu lugar de natureza.

Por meio dela, colabora-se para levantar hierarquias socialmente construídas entre o mundo humano e o mundo não humano.

A pandemia tornou essa realidade de dependência anda mais evidente e, mais uma vez, é a ciência quem confirma tal realidade. A pandemia permitiu acelerar nossa compreensão, por meio da ciência, de que existe uma dependência entre o mundo humano e o mundo não humano.

A ciência, especialmente a ciência climática, afirma que os sistemas naturais devem ser protegidos, e o devem ser, por meio Direito, e de uma abordagem que favoreça decisões em seu favor.

Nesse sentido, a partir da próxima seção, se poderá enfrentar o problema proposto neste trabalho, que diz respeito à justificação, por meio do Direito, de modelos de decisão em favor da natureza (decisões pro natura)

Decisões pro natura dependem, ante de tudo, de estruturas institucionais ecologicamente sensíveis. Essas estruturas serão capazes de favorecer a transformação dos padrões de decisão pro natura, para além de oportunidades de adjudicação ecológica que se limitem a solucionar casos de dúvidas, por sua vez, ancoradas em um sentido restritivo de um princípio in dubio pro natura.

A próxima seção sustenta que a oportunidade para decisões pro natura deve ser compreendida, antes de tudo - ao menos no contexto constitucional brasileiro — a partir dos imperativos ecológicos definidos por uma ordem jurídica ecologicamente sensível, e não pode ser limitada à aplicação restritiva de um princípio in dubio pro natura.

\section{Constituição e sensibilidade ecológica: a normatividade da integridade ecológica na Constituição Federal de 1988}

Como resposta a uma crescente crise ecológica, o discurso de proteção ambiental, que se deu com mais força primeiramente no plano normativo internacional ${ }^{46}$, foi absorvido posteriormente pelas metas e objetivos estatais, fato que resultou na inclusão gradativa, pelos Estados, do

Disponível em: < https://www.pnas.org/content/105/6/1786> Acesso em: 30 out. 2020.

46 No início de 1970, as primeiras preocupações legais com o ambiente baseavam-se, em sua maioria, em questões de poluição transfronteiriça e proteção específica e fragmentada da fauna e flora (WEISS, Edith Brown. Rule of law for nature in a kaleidoscopic world. In: VOIGT, Christina (Ed.). Rule of Law for Nature: New dimensions and Ideas in Environmental Law. Cambridge: Cambridge University Press, 2013, p. 28). A Conferência de Estocolmo denunciou a conexão entre degradação ambiental e ações antrópicas, principalmente as decorrentes da expansão do processo econômico, afirmando a urgente necessidade de abordar o processo de desenvolvimento humano do ponto de vista da proteção ambiental, tornando-se um marco jurídico de relevância para a consolidação daquilo que viria a ser reconhecido como o direito internacional ambiental. 
meio ambiente como um bem jurídico em suas constituições.

Para muito além das tradicionais responsabilidades para com direitos, garantias e liberdades individuais, a Constituição da República de 1988 se expressa em uma ordem jurídica ecologicamente sensivel, firmada sob um compromisso político mais solidário e uma arquitetura moralmente expandida, de forma a favorecer um modelo normativo de valoração diferenciado, como é o caso da inclusão no seio da normativa ambiental constitucional do respeito à integridade ecológica.

O artigo 225, inciso I, $\int 1^{\circ}$, aloca como dever do Poder Público a preservação e restauração dos processos ecológicos essenciais, e de igual modo, devendo prover ainda o manejo ecológico das espécies e ecossistemas. Trata-se de um imperativo fundamentalmente ecológico ${ }^{47}$, que denota, antes de tudo, uma abertura normativa à recepção de preocupações essencialmente ecológicas.

A noção de sensibilidade ecológica (ecological sensitivity) é utilizada por Oren Perez para definir de que forma a percepção de preocupações ecológicas é levada em consideração por instituições, normas ou políticas — e, em sua obra, especificamente, em relação aos conflitos em torno da dialética comércio-meio ambiente em um sistema econômico global ${ }^{48}$.

O conceito, portanto, representa a noção de que a receptividade à preocupações ecológicas pelas normas se encontra suscetível a diferentes niveis de sensibilidade, que podem ser aferidos pela força de influência que exercem, em maior ou menor grau, os problemas ecológicos à consideração — no presente caso — do direito constitucional, o que pode sugerir uma percepção de sensibilidade ou insensibilidade ecológica ${ }^{49}$.

Para os fins da pesquisa apresentada neste artigo, a receptividade da consideração em torno de preocupações ecológicas se dá pelo compromisso das normas jurídicas com a proteção dos sistemas terrestres. Assumir esse compromisso particularizado — que vai além da garantia de interesses pautados na satisfação de utilidades — ressalta que as normas jurídicas de um sistema constitucional ecologicamente sensível precisam estar suscetíveis à adequada ponderação das preocupações que envolvem a integridade dos sistemas terrestres, e dos problemas infligidos aos sistemas ecológicos pelas condutas humanas de uso do, e de interação com o ambiente.

A compreensão de uma sensibilidade ecológica, nesse caso, salienta a incorporação de deveres constitucionais que permitam definir a noção de que os limites da natureza sejam considerados para a elaboração de normas jurídicas.

Isso quer significar, em outras palavras, que o direito deve levar em consideração a ciência dos sistemas terrestres.

A noção de sensibilidade constitui condição de suscetibilidade das normas jurídicas à incorporação de preocupações essencialmente ecológicas. A definição de uma norma ecologicamente sensível, portanto, propõe que é necessário considerar uma real percepção dos sistemas ecológicos.

É nesse sentido que se afirma que normas jurídicas ecologicamente sensiveis não podem ignorar as leis da natureza. Em um parâmetro normativo, o artigo 225 da Constituição Federal de 1988 denota sensibilidade ecológica, visto fazer referência à proteção do ambiente por meio de deveres estatais, cujo objetivo primário são a proteção de processos ecológicos essenciais (inciso I, $\int 1^{\circ}$,) e da função ecológica (inciso VII, $\int 1^{\circ}$ ).

\footnotetext{
47 Nesse sentido, Ingo Sarlet e Tiago Fensterseifer: “(...) no sistema constitucional brasileiro (art. 225), as expressões 'processos ecológicos essenciais’ e 'função ecológica', inclusive com vedação expressa a práticas que provoquem a extinção de espécies da biodiversidade, também refletem o conteúdo e princípio da integridade ecológica. De tal sorte, pode-se alegar que a integridade ecológica pode (e deve) ser reconhecida como um princípio constitucional implícito do regime constitucional ecológico edificado pela nossa Lei Fundamental de 1988.”. (SARLET, Ingo Wolfgang; FENSTERSEIFER, Tiago. Direito constitucional ecológico: constituição, direitos fundamentais e proteção da natureza. 6. Ed. São Paulo: Thomson Reuters Brasil, 2019. p. 76-77).

48 PEREZ, Oren. Ecological Sensitivity and Global Legal Pluralism: Rethinking the Trade and Environment Conflict. Oxford: Hart Publishing, 2004. P. 23-29.

49 PEREZ, Oren. Ecological Sensitivity and Global Legal Pluralism: Rethinking the Trade and Environment Conflict. 2004, p. $23-29$.
} 
Pode-se alegar que as referências insertas nos incisos I e VII, do $\int 1^{\circ}$, do art. 225 , se contextualizam enquanto constitucionalização implícita de um princípio de integridade ecológica ${ }^{50}$, que atuam de forma a vincular a atuação estatal (deveres constitucionais) em benefício do respeito aos limites ecológicos.

Por integridade ecológica, entende-se as condições e características físicas, biológicas e químicas que compõem e determinam a integridade, a existência e a manutenção de um ecossistema ${ }^{51}$. Isto é, trata-se de um conjunto de atributos ecológicos que permitem a identificação e caracterização de um ecossistema. Um dever constitucional de proteger os processos ecológicos deve se apresentar enquanto correta percepção do que se compreende por sistema ecológico.

Isso ressalta que, em um cenário de contraperspectiva, um direito que não enxerga a natureza poderia ser definido como um direito ecologicamente insensivel, ou menos sensibilizado, na medida em que o que se precisa considerar é o conjunto de preocupações relativo não à necessidade humana de acesso aos recursos naturais, senão com a própria condição dos sistemas ecológicos.

A noção ecológica para um Estado Constitucional, nesse sentido, parte de um Estado estruturado sob a consideração de valores e objetivos que definem a complexidade dos processos sociais na pós-modernidade a partir de um imperativo de proteção ecológica. Nesta pesquisa considera-se que esse imperativo de proteção ecológica identificaria um direito ecologicamente sensivel. Trata-se de um modelo jurídico que se encontra fundamentado em uma abordagem ecológica para os direitos, e que necessariamente deve ser orientado pela ciência dos sistemas terrestres.

O texto do artigo 225, $\int 1^{\circ}$, incisos I e VII, especialmente, da Constituição Brasileira, propõe imperativos ecológicos de proteção cujo conteúdo veicula, objetivamente, deveres estatais de não se violar os limites planetários, e de se respeitar a integridade dos processos ecológicos e dos sistemas naturais. A noção de uma constituição ecologicamente sensível permite que se compreenda como juridicamente possível uma abordagem ecológica dos direitos no interesse do sistema terra.

Especialmente em relação a um dos limites planetários, a biodiversidade, não é possível que, com base no artigo 225, $\int 1^{\circ}$, incisos I e VII, da CRFB de 1988, escolhas ou decisões públicas ou privadas violem e se afastem dos limites planetários, ou que comprometam a integridade dos sistemas naturais, na medida em que se encontram vedados todos os atos, práticas, decisões ou escolhas que frustrem a função ecológica da fauna e da flora, comprometam a integridade dos processos ecológicos, não permitam sua restauração, colaborem para a extinção da existência da vida não humana, ou, ainda, que não respeitem sua existência sob o ângulo da senciência, infligindo dor e sofrimento.

Portanto, em um mundo em transformação, a proteção jurídica da natureza passa, antes de tudo, por levar a sério a Constituição. E levar a sério a Constituição, em semelhante contexto, estrutura-se em favorecer a aplicação da Constituição que favoreça compromissos com o Sistema Terrestre, com os sistemas naturais e seus processos ecológicos.

É nesse sentido que se procura propor, na próxima seção, que intervenções antropogênicas em contextos de comprometimento dos limites planetários justificam um parâmetro pro natura para a tomada de decisões.

Portanto, as duas últimas seções partirão de proposições orientadas pela ciência climática para um sentido ecológico do in dubio pro natura, que deve se encontrar, antes de tudo, estruturado e bem justificado em um arranjo no qual não se possa permitir que decisão, escolha ou o exercício das liberdades ultrapassem os limites objetivos da existência dos sistemas naturais, garantidos pelos imperativos ecológicos de uma constituição ecologicamente sensível.

50 SARLET, Ingo Wolfgang; FENSTERSEIFER, Tiago. Direito constitucional ecológico: constituição, direitos fundamentais e proteção da natureza. 6. ed. São Paulo: Thomson Reuters Brasil, 2019. p. 77.

51 BOSSELMANN, Klaus. Loosing the forest for the trees: environmental reductionism in the law. 2010. p. 2439. 


\section{A Virada ecológica dos direitos no interesse do sistema terra: os princípios da integridade ecológica e in dubio pro natura}

Conforme foi exposto na seção anterior, definições relevantes de ciência climática se encontram acolhidas pelo texto do artigo 225, $\ 1^{\circ}$, incisos I e VII, da CRFB de 1988, sendo possível justificar, por meio de sua normatividade, uma aproximação entre Direito e os sistemas naturais e, sobretudo, justificar uma virada ecológica dos direitos, no contexto da ordem jurídica brasileira ${ }^{52}$, identificada, neste artigo, com base na definição de ecologicamente sensível.

O reconhecimento de sua existência em âmbito nacional não pode ser apartado, entretanto, de um diálogo que ela estabelece com a ordem jurídica internacional e com outras ordens jurídicas nacionais, estando nesse diálogo um caminho de fortalecimento de uma abordagem ecológica para direitos, nomeadamente por meio da afirmação de dois princípios representativos daquela aproximação já referida: os princípios da integridade ecológica e in dubio pro natura.

Muito embora as normas que regulem a proteção jurídica da natureza nem sempre se encontrem dispostas sob a condição de normas imperativas, é possível considerar, pelo menos, três argumentos que justificariam a possibilidade de interação entre a ordem jurídica internacional e a doméstica, em outros níveis de vinculação.

Dinah Shelton salienta, antes de tudo, como primeiro argumento, que — para além das fontes associadas aos tratados, costumes, das normas de jus cogens, de decisões de tribunais internacionais, e de outras fontes, tais como, declarações, resoluções e recomendações — também não pode ser ignorada a possibilidade de uso indireto do direito internacional, como instrumento de informação do direito doméstico. ${ }^{53}$

Em segundo lugar, não se pode considerar que normas vinculantes sejam mais eficazes do que aquelas que não o sejam. Dinah Shelton observa mesmo que, às vezes, o cumprimento de normas não vinculativas é extremamente bom e provavelmente não seria se estas estivessem contidas em textos vinculativos. ${ }^{54}$

Por outro lado, também se deve considerar que mesmo instrumentos que não ostentem a condição de hard law podem conter normas imperativas, sendo este precisamente o caso do princípio 21 da Declaração de Estocolmo, pelo qual a soberania dos Estados encontra limites no dever de não prejudicar o meio ambiente. $^{55}$

Sem pretender enfrentar o tema associado ao modo de incorporação e de relacionamento do direito internacional com o direito interno brasileiro — naquilo que se encontre associado ao problema da incorporação do direito internacional imperativo- para o propósito deste texto - , considera-se que o relacionamento de uma ordem jurídica não imperativa - locus normalmente associado ao direito internacional do meio ambiente, que pode conter acordos de implementação mais ou menos flexível ${ }^{56}$ — se estabeleça por meio de diálogos colaborativos entre ordens jurídicas, no interesse da proteção de valores de interesse existencial emergente.

52 SARLET, Ingo; FENSTERSEIFER, Tiago. Direito Constitucional Ecológico. 6. ed. São Paulo: RT, 2019. p. 15-26; SARLET, Ingo; FENSTERSEIFER, Tiago. Curso de Direito Ambiental. Rio de Janeiro: Forense, 2020. p. 67-71; SOZZO, Gonzalo. Derecho Privado Ambiental. El Giro Ecológico del Derecho Privado. Santa Fe: Rubinzal-Culzoni, 2019; LEITE, José Rubens Morato; AYALA, Patryck de Araujo; CAPDEVILLE, Fernanda Cavedon; MELO, Melissa Ely; SILVEIRA, Paula Galbiatti; DAROS, Leatrice Faraco. A Ecologização do Direito Ambiental Vigente. Rupturas Necessárias. Rio de Janeiro: Lumen Juris, 2018.

53 SHELTON, Dinah. Introduction. In: SHELTON, Dinah. (Coord.). International Law and Dometic Legal Systems: Incorpotation, Transformation and Persuasion. Oxford: Oxford University Press, 2011. p. 19.

54 SHELTON. Dinah. Soft Law. Disponível em: https://ssrn.com/abstract=1003387. Acesso em: 20 mai. 2019.

55 BRUNNEE, Jutta. The Stockholm Declaration and the Structure and Processes of International Environmental Law. In: CHIRCOP, Aldo; MCDORMAN, Ted. (Ed.). The Future of Ocean REgime Building: Essays in Tribute to Douglas M. Johnston. Kluwer, 2008. p. 42-44.

56 BRUCH, Carl. Is International Environmental Law Really Law?: An Analysis of Application in Domestic Courts. Pace Environmental Law Review, n. 23, p. 424, 2006. 
Para além de um diálogo de fontes - tal como proposto por Jayme, com o escopo de assegurar a coexistência coerente de normas em uma mesma ordem jurídica, garantida a influência recíproca de todas elas no processo de aplicação e no interesse da solução mais justa ${ }^{57}$ - o diálogo se realiza em uma proposta de colaboração entre ordens jurídicas no interesse de se favorecer um pluralismo jurídico que represente uma comunidade de interesses em transformação.

Isso somente seria possível, conforme salienta Mireille Delmas-Marty com o “[...] desenvolvimento de estruturas jurídicas que talvez anunciem, com seu funcionamento simultâneo sem ser unificado, o nascimento de um pluralismo 'jurídico', ou seja, ordenado" 58 .

Nesse plano de argumentação, a existência de documentos internacionais que implicam uma noção de responsabilidade ecológica para o Direito passa pelo reconhecimento de que os sistemas ecológicos representam, antes de tudo, limites a ações antrópicas. Noções como limites planetários ${ }^{59}$ e integridade ecológica ${ }^{60}$ — manifestações jurídicas sensíveis à proteção da natureza — são definidas em modelos internacionais como os Objetivos do Desenvolvimento Sustentável (ODS) e a Carta da Terra, e precisam, igualmente, ser considerados como objetivos relevantes para as ordens jurídicas domésticas.

Nesse sentido, um paradigma de avanço em matéria de direitos ambientais e proteção dos sistemas ecológicos é claramente reconhecido pela abordagem dos ODS que, adotados em 2015, na Cúpula das Nações Unidas para o Desenvolvimento Sustentável, devem pautar as políticas nacionais e as ações de cooperação internacional ${ }^{61}$.

O discurso de sustentabilidade adotado nos ODS assume um caráter integrado e sistêmico não somente para a proteção dos direitos humanos, senão também para o reconhecimento de responsabilidades de proteção dos sistemas ecológicos, cujo objetivo principal é o de promover condições sustentáveis para uma vida justa ${ }^{62}$.

Uma noção real de sustentabilidade em um contexto do Antropoceno, portanto, implica a observação dos limites planetários, o que sugere, por si só, um nível mínimo de proteção ambiental exigido dentro de um contexto mais amplo de desenvolvimento sustentável ao longo prazo ${ }^{63}$.

Em um contexto similar, é por meio do comprometimento ético para um mundo justo, sustentável e pacífico, e pela consideração da unidade entre a vida humana e não humana ${ }^{64}$ que a Carta da Terra — documento internacional oriundo do consenso de grande parte da sociedade civil global ${ }^{65}$ — abarca, em seu rol de princípios, conceitos como integridade ecológica, direitos humanos e justiça social e econômica, ajustando como fundamentos o objetivo de se alcançar uma sociedade sustentável e de paz ${ }^{66}$.

57 Cf. JAYME, Erik. Jayme, Erik, Identité culturelle et intégration : le droit international privé postmoderne. In: Collected Courses of the Hague Academy of International Law. Leiden: Martinus Nijhoff, 1995. p. 60.

58 DELMAS-MARTY, Mireille. Por um direito comum. São Paulo: Martins Fontes, 2004, p. 238.

59 STEFFEN, Will; RICHARDSON, Katherine; ROCKSTROM, Johan; Et al. Planetary boundaries: Guiding human development on a changing planet. Science, v. 347. 2015. Disponível em: < https://science.sciencemag.org/content/347/6223/1259855> Acesso em: 21 set. 2020.

60 BOSSELMANN, Klaus. Losing the forest for the trees: environmental reductionism in the Law. Sustainability, 2010. p. 2439.

61 LEITE, José Rubens Morato; SILVEIRA, Paula Galbiatti. A Ecologização do Estado de Direito: uma Ruptura ao Direito Ambiental e ao Antropocentrismo Vigentes. In: LEITE, José Rubens Morato et al. A Ecologização do Direito Ambiental Vigente: Rupturas Necessárias. LEITE, José Rubens Morato. Rio de Janeiro: Lumen Juris, 2018. p. 117.

62 Vide os 17 objetivos elencados: <https://nacoesunidas.org/pos2015/>

63 KIM, Rakhyun E.; BOSSELMANN, Klaus. International Environmental Law in the Anthropocene: Towards a Purposive System of Multilateral Environmental Agreements. Transnational Environmental Law, v. 2, issue 02, 2013. p. 290.

${ }^{64}$ BOSSELMANN, Klaus. O princípio da sustentabilidade: transformando direito e governança. São Paulo: Editora Revista dos Tribunais, 2015. p. 180.

65 BOSSELMANN, Klaus; TAYLOR, Prue. The Significance of the Earth Charter in International Law. The Way Foward, 2009. Disponível em: <http://earthcharterinaction.org/pdfs/TEC-ENG-PDF/ENG-Bosselmann.pdf> Acesso em: 20 jun. 20.

${ }_{66}$ De acordo com o preâmbulo da Carta da Terra. UNESCO. The Earth Charter. Disponível em: < http://www.unesco.org/education/tlsf/mods/theme_a/img/02_earthcharter.pdf> Acesso em: 29 jun. 2020. p. 1. 
Há uma fundamental importância na escolha dos princípios gerais na Carta da Terra, sendo o Princípio da Integridade Ecológica um imperativo relevante para a adequada proteção e restauração da integridade dos sistemas ecológicos e dos processos naturais que sustentam a vida (princípio II, 5. ${ }^{67}$, inclusive por meio da aplicação de princípios como prevenção e precaução (princípio II, 6. ${ }^{68}$.

Nesse contexto, prevenção e precaução são situados como princípios específicos de conduta para a aplicação de um princípio geral de proteção e restauração da integridade dos sistemas ecológicos, de modo a operacionalizar a observância deste imperativo de proteção e preservação da natureza.

Esse mesmo imperativo de proteção da natureza se encontra bem representado em princípio que tem sua afirmação expressa, dessa vez, em ordem jurídica nacional distinta, a saber, o texto da Constituição equatoriana de 2008: o princípio in dubio pro natura. ${ }^{69}$

Inicialmente afirmado pelo artigo 395.4 do texto vigente da Constituição do Equador, o princípio in dubio pro natura preceitua que "[...] no caso de dúvida sobre o alcance das disposições legais em matéria ambiental, estas serão aplicadas no sentido mais favorável à proteção da natureza."’0

Esse mesmo sentido é expressamente acolhido no Brasil pelo STJ, tendo-o sido especialmente nos autos do RESp n. 1.668.652/PA e do RESP n. 1.356.207/SP, ocasião em que foi para o fim de favorecer a aplicação do conteúdo ambiental das normas jurídicas — obstando sentidos que fossem incompatíveis com semelhante finalidade —, muito embora não seja possível afirmar que sempre se estivesse concretamente em contexto de dúvida ou de conflito que exigisse o uso da norma principiológica como instrumento determinante para a decisão ${ }^{71}$.

Por outro lado, o tribunal também acolhe sentido mais específico, que se aproxima do fortalecimento do Princípio de Reparação Integral dos Danos.

É assim que o tribunal fixou seu uso para o fim de justificar que os assim denominados danos interinos, intersticiais e futuros, também não poderiam deixar de ser inclú́dos sob o alcance das medidas de reparação de danos associadas ao regime de responsabilização civil definido pela ordem jurídica nacional ${ }^{72}$. Da mesma forma, também justificou, com base no mesmo princípio, a possibilidade de acumulação das obrigações de reparação e de recomposição in natura, bem como a reparação dos danos extrapatrimoniais coletivos ${ }^{73}$

67 UNESCO. The Earth Charter, p. 3.

68 UNESCO. The Earth Charter, p. 3.

69 Para uma análise detalhada do princípio e seu significado no contexto latino-americano, conferir a exaustiva pesquisa realizada em: CAPPELLI, Silvia. In dubio pro natura. Revista de Direito Ambiental, v. 98, p. 197-223, Abr./Jun. 2020.

70 ECUADOR. Assamblaya Constituyente. Constitución del Ecuador. Disponível em: <https://www.oas.org/juridico/mla/sp/ecu/ sp_ecu-int-text-const.pdf>. Acesso em: 04 set. 2020. Lê-se no original: "En caso de duda sobre el alcance de las disposiciones legales em materia ambiental, éstas se aplicarán en el sentido más favorable a la protección de la naturaleza.”.

71 BRASIL. Superior Tribunal de Justiça. REsp 1668652/PA. Recurso Especial 2017/0086149-3, 27 de novembro de 2018. Diário da Justiça, DF, 08 fev. 2019. Disponível em: <http://www.stj.jus.br/>. Acesso em: 02 jul. 2020; BRASIL. Superior Tribunal de Justiça. REsp 1356207/SP. Recurso Especial 2012/0251709-6, 28 de abril de 2015. Diário da Justiça, DF, 07 mai. 2015. Disponível em: <http://www.stj.jus.br/>. Acesso em: 02 jul. 2020.

72 BRASIL. REsp 1669185/RS. Recurso Especial 2017/0098505-6, 05 de setembro de 2017. Diário da Justiça, DF, 20 out. 2017. Disponível em: <http://www.stj.jus.br>. Acesso em: 02 jul. 2020; BRASIL. REsp 1255127/MG. Recurso Especial 2011/00914990, 18 de agosto de 2016. Diário da Justiça, DF, 12 set. 2016. Disponível em: <http://www.stj.jus.br>. Acesso em: 02 jul. 2020 ; BRASIL. Superior Tribunal de Justiça. REsp 1328753/MG. Recurso Especial 2012/0122623-1, 28 de maio de 2013. Diário da Justiça, DF, 03 fev. 2015. Disponível em: <http://www.stj.jus.br/>. Acesso em: 02 jul. 2020; BRASIL. REsp 1198727/MG. Recurso Especial 2010/0111349-9, 14 de agosto de 2012. Diário da Justiça, DF, 09 mai. 2013. Disponível em: < http://www.stj.jus.br/>. Acesso em: 02 jul. 2020; BRASIL. REsp 1145083/MG. Recurso Especial 2009/0115262-9, 27 de setembro de 2011. Diário da Justiça, DF, 04 set. 2012. Disponível em: <http://www.stj.jus.br/>. Acesso em: 02 jul. 2020; BRASIL. Superior Tribunal de Justiça. REsp 1180078/MG. Recurso Especial 2010/0020912-6, 02 de outubro de 2010. Diário da Justiça, DF, 28 fev. 2012. Disponível em: <http://www.stj.jus.br>. Acesso em: 02 jul. 2020; BRASIL. REsp 1114893/MG, Recurso Especial 2008/0243168-8, 16 de março de 2010. Diário da Justiça, DF, 28 fev. 2012. Disponível em: <http://www.stj.jus.br/>. Acesso em: 02 jul. 2020.

73 BRASIL. Superior Tribunal de Justiça. REsp 1269494/MG. Recurso Especial 2011/0124011-9, 24 de setembro de 2013. Diário da Justiça, DF, 01 out. 2013. Disponível em: <http://www.stj.jus.br/>. Acesso em: 02 jul. 2020; BRASIL. Superior Tribunal de Justiça. REsp 1367923/RJ. Recurso Especial 2011/0086453-6, 27 de agosto de 2013. Diário da Justiça, DF, 06 set. 2013. Disponível 
(ambas já reconhecidas pelo tribunal em ocasiões anteriores, sob fundamentos distintos ${ }^{74}$ ), ou, ainda, da inversão do ônus da prova como manifestação de um princípio da precaução. ${ }^{75}$

Embora a origem de seu conteúdo esteja relacionada a contextos de dívida sobre a aplicação de normas, ou sobre contextos de incerteza científica, ou ainda, a contextos de incerteza sobre a avaliação dos fatos em matéria ambiental, não parece ser possível justificar que a virada ecológica de direitos em curso, especialmente na América Latina, acolha a aplicação de um sentido restritivo do princípio. Nessa abordagem restritiva, ter-se-ia que o princípio se apresentaria na condição de mero instrumento de resolução de controvérsias de natureza ambiental que envolvam contextos de dúvida, quando e somente então seria possível favorecer uma solução em favor da natureza.

Sustenta-se que uma estrutura dialógica que relacione a ordem jurídica internacional não imperativa, a ordem jurídica nacional e a atividade jurisprudencial estrangeira, com a ordem jurídica doméstica, permitiria justificar a emergência de um Direito Ecológico, designando-lhe pela coordenação dos princípios anteriormente descritos, o objetivo de respeitar os limites planetários.

A próxima seção ilustrará essa projeção ecológica do Direito, nomeadamente pela exposição da jurisprudência selecionada dos tribunais equatorianos, colombianos, mexicano, argentino, e da CIDH. A seleção jurisprudencial tem por finalidade ilustrar que, se um dos imperativos designados ao Direito no contexto de emergências planetárias é permitir justificar-se decisões em favor da natureza, a afirmação de que a natureza possui um valor intrínseco e autônomo - tal como reconhecido pela CIDH - e a afirmação de que a natureza também deve possuir direitos caminham na direção de que os sistemas naturais já constituem objeto de imperativos de proteção.

Nesse sentido a próxima seção pretende justificar que um imperativo jurídico de in dubio pro natura pode ser melhor compreendido no contexto de uma estrutura jurídica que já posiciona a natureza em um contexto de prioridade, na medida em que os sistemas de direitos — incluído o brasileiro — acolhem conteúdos e definições circunscritos à ciência do Sistema Terrestre, e ao respeito dos limites dos sistemas naturais.

\section{6 in dubio pro natura?}

A terceira e quarta seções demonstraram que a ordem constitucional brasileira, em diálogo com a experiência normativa internacional, acolhe possibilidades de se justificarem decisões pro natura mediante a afirmação de compromissos jurídicos com a integridade dos sistemas naturais, e dos processos ecológicos que sejam essenciais. Essa justificação se faz possível, inclusive, mediante a expressa aplicação de um princípio in dubio pro natura, pela jurisprudência do STJ ${ }^{76}$.

Sustentou-se, assim, que justificar respostas jurídicas pro natura dependeria, primeiramente, de se levar a sério a Constituição ecológica.

Nessa oportunidade se desenvolve o argumento pelo qual levar a sério a Constituição Ecológica materializa não apenas uma transformação sobre os sistemas de direitos, senão influencia a ampliação do conteúdo

em: <http://www.stj.jus.br>. Acesso em: 02 jul. 2020.

74 Sobre a possibilidade de acumulação das obrigações é conveniente salientar que o STJ confirmou a conclusão por meio da tese n. 1, vinculado ao julgamento de 74 precedentes. Cf. BRASIL. Superior Tribunal de Justiça. Jurisprudência em Teses. Disponível em: $<$ http://www.stj.jus.br/SCON/jt/toc.jsp>. Acesso em 02 jul. 2020.

75 BRASIL. Superior Tribunal de Justiça. REsp 883.656/RS. Recurso Especial 2006/0145139-9, 09 de março de 2010. Diário da Justiça, DF, 28 fev. 2012. Disponível em: <http://www.stj.jus.br/>. Acesso em: 02/04/2019. A matéria também é objeto da tese de n. 4 do STJ, oriunda de 33 precedentes. Cf. BRASIL. Superior Tribunal de Justiça. Jurisprudência em Teses. Disponível em: < http:// www.sti.jus.br/SCON/jt/toc.jsp>. Acesso em 02 jul. 2020.

76 LEITE, José Rubens Morato; VENÂNCIO, Marina Demaria. Environmental Protection in Brazil's High Court: safeguarding the environment through a Rule of Law for Nature, Sequência, n. 77, p. 29-50, nov. 2017. 
para o mesmo princípio in dubio pro natura.

Mediante a afirmação de que um Direito ecológico aproxima as instituições e os sistemas naturais, demonstrar-se-á - por meio da jurisprudência nacional de tribunais latino-americanos e da CIDH — que esse movimento de aproximação do Direito em relação à natureza também é responsável pela ampliação do conteúdo para o referido princípio.

Sob essa perspectiva se pretende contextualizar - a partir do giro ecológico na jurisprudência latino-americana - que não mais se pode restringir a justificação de decisões pro natura a contextos de dúvida interpretativa sobre a aplicação de normas jurídicas ambientais ${ }^{77}$.

Se o Direito deve respeitar os sistemas naturais, Isabelle Stengers et al. propõem que deva ser feita uma pergunta antes de todas as outras. Como instituir uma natureza que respeite e considere o que importa para os cientistas? ${ }^{78}$

Normalmente quem toma decisões aceita a hipótese de que existe um sistema terrestre autorregulado, mas as ciências naturais não a aceitam.

Isabelle Stengers et al. afirmam que não se trata nem de propor uma natureza hegemônica, nem, de outro lado, uma natureza domesticada. ${ }^{79}$

Gaia não pode ser compreendido como um retorno às leituras de uma harmonia da natureza.

Conforme explicam Bruno Latour e Timothy Lenton, o que James Lovelock propõe em Gaia, e Lyn Margullis o faz em Planeta Simbiótico, é atribuir às formas de vida, a elas mesmas, a tarefa de criar as condições de longo prazo para se expandirem no espaço, obedecendo as suas próprias leis. As distinções entre ambas são apenas de escala, planetária em James Lovelock, e celular, e Lyn Margullis. ${ }^{80}$

Bruno Latour, em sua quarta conferência das Gifford Lectures, assinala que o Antropoceno nos traz uma referência de que a Terra é instável. ${ }^{81}$

Não se trata de fazer o uso indiscriminado da noção de totalidade e de atribuir à Gaia uma referência de organismo que determina e orienta todas as nossas ações.

O Antropoceno deixou os humanos mais geológicos, e sua presença na Terra é compreendida por meio de relações e conexões que este estabelece com a Terra ${ }^{82}$.

No lugar da definição de globo (totalidade), é proposta a consideração de uma noção de ciclos.

No lugar de uma reverência ao todo, são enfatizadas as conexões. Gaia é sensível à ação humana e reage muito rapidamente. Essas conexões são aquelas que precisam ser respeitadas no Antropoceno ${ }^{83}$.

Isabelle Stengers et al., mais uma vez, dirão que civilizar a natureza significa que nós pertencemos à Terra, mas a natureza não é algo que possa ser definida de um vez por todas e não pode mobilizar o conhe-

\footnotetext{
77 No Brasil, a noção de um mandado in dubio pro natura foi referida pela primeira vez pelo professor Luiz Fernando Coelho, em trabalho publicado no ano de 1994. Em texto mais recente, desenvolvendo 11 teses para o Direito Ambiental, sustenta que conflitos normativos são resolvidos pela aplicação da tese in dubio pro natura. Desse modo, no caso de conflitos normativos se deveria sempre adotar a solução qeu favoreça a proteção ambiental. COELHO, Luiz Fernando. Dogmática, Zetética e Crítica do Direito, Rev. Ciên. Jur. e Soc. da Unipar, v. 11, n. 1, p. 308, jan./jun. 2008.

78 STENGERS, Isabelle et al. Restituing Nature: A Latourian Workshop. Environmental Humanities, v. 6, p.169, 2015.

79 STENGERS, Isabelle et al. Restituing Nature: A Latourian Workshop. Environmental Humanities, v. 6, p.169, 2015.

80 LATOUR, Bruno, LENTON, Timothy M. Extending the Domain of Freedom, or Why Gaia Is So Hard to Understand. Critical Inquiry, v. 45, n. 3. Springer 2019. p. 5.

81 LATOUR, Bruno, LENTON, Timothy M. Extending the Domain of Freedom, or Why Gaia Is So Hard to Understand. Critical Inquiry, v. 45, n. 3. Springer 2019. p. 5.

82 LATOUR, Bruno. Facing Gaia. Eight Lecture on the New Climatic Regime. London: Polity, 2017.

83 LATOUR, Bruno, LENTON, Timothy M. Extending the Domain of Freedom, or Why Gaia Is So Hard to Understand. Critical Inquiry, v. 45, n. 3. Springer 2019. p. 5.
} 
cimento da humanidade na busca de respostas diretas ${ }^{84}$.

A obrigação (ou o dever) de respeitar as leis da natureza pode suscitar graus diferenciados da identidade de um Estado de direito para a natureza: desde restrições ao uso dos recursos naturais decorrente de sua condição de trust, e da necessidade de se não serem violadas as relações ou os processos fundamentais que sustentam todas as formas de vida, até o reconhecimento, à natureza, da mesma posição moral (e jurídica), em uma comunidade de direitos.

Dito em outras palavras, um Estado de direito para a natureza pode propor faces mais moderadas ou mais rígidas em uma comunidade de direitos: de deveres (dos homens) para com a natureza, até direitos (ao menos alguns, e aqueles que estejam diretamente adstritos à conservação e não intervenção sobre as leis naturais básicas), para a natureza, concebendo-a como sujeito desses mesmos direitos.

Se a primeira abordagem não é desconhecida da maior parte dos sistemas jurídicos (e constitucionais) ocidentais, e expressa na maior parte dos casos por meio de um direito fundamental ao ambiente que impõe restrições ou condicionamentos das liberdades econômicas (de onde a propriedade e as liberdades são os valores mais afetados), a segunda abordagem, de matriz notadamente ecocêntrica, vem ganhado força especialmente naquele movimento que se denomina como constitucionalismo latino-americano ${ }^{85}$.

Para o efeito deste trabalho, o direito constitucional latino-americano ensina preciosas e recentes lições sobre como lidar com a proteção da natureza.

A Constituição equatoriana atribui à natureza a condição de sujeito (artigo 10), define expressamente direitos (artigo 71) e é o único texto no mundo que se refere, de forma direta, a um princípio in dubio pro natura (artigo 395.4).

A Constituição colombiana não define direitos da natureza, mas seus tribunais o fizeram em sucessivas oportunidades a partir do ano de 2016 e até a data de 02 de setembro de 2020, data da mais recente decisão que favorece ou afirma, de forma expressa, a condição de sujeito à própria natureza ${ }^{86}$. O Tribunal Constitucional reconheceu direitos a rios $^{87}$, o Supremo Tribunal de Justiça os atribuiu à Amazônia colombiana ${ }^{88} \mathrm{e}$, posteriormente, à via parque Ilha de Salamanca ${ }^{89}$, e mais recentemente podem ser citadas as decisões do: a) Tribunal Superior do Distrito de Ibagué, quem atribuiu direitos ao Parque Nacional Natural Los Nevados a condição de sujeito de direitos ${ }^{90}$; b) do Quarto Juizado de Execução de Penas e de Medidas de Segurança,

84 STENGERS, Isabelle et al. Restituing Nature: A Latourian Workshop. Environmental Humanities, v. 6. 2015. p.172-173.

85 Sobre o tema, cf. GARGARELLA, Roberto. Explicando o constitucionalismo latino-americano. Journal of the Max Planck for European Legal History, n. 24, p. 336-338, 2014.

86 A última decisão é proveniente do Conselho de Estado colombiano, cujo acórdão ainda não foi publicado, tendo por objeto a proteção da baía de Cartagena. Cf.: El Espectador. El histórico fallo para proteger la bahía de Cartagena. 2020. Disponível em: <https:// www.elespectador.com/noticias/judicial/el-historico-fallo-para-proteger-la-bahia-de-cartagena/>. Acesso em: 04 set. 2020.

87 Trata-se da sentença T-622/16, reconhecendo a condição de sujeito de direito ao rio Atrato. Cf.: COLÔMBIA. Corte Constitucional. Sentencia T-622/16, 10 de noviembre de 2016. Consejo Comunitario Mayor de la Organización Popular Campesina del Alto Atrato, Consejo Comunitario Mayor de la Asociación Campesina Integral del Atrato, Asociación de Consejos Comunitarios del Bajo Atrato, Foro Inter-Étnico Solidariedad Chocó y Otros versus Presidencia de la Republica y Otros. Disponível em: <https://www. corteconstitucional.gov.co/relatoria/2016/t-622-16.htm>. Acesso em 20 de jul. 2020.

88 COLÔMBIA. Corte Suprema de Justicia. Radicación 11001-22-03-000-2018-00319-01, 5 de abril de 2018. Victoria Alexandra Arena Sanchez, José Daniel y Felix Jeffry Rodriguez Peña y Otros versus Presidencia de la Republica, Ministerio de Ambinte y Desarollo Sostenible, Ministerio de Agricultura y Desarollo Rural, Unidad Administrativa Especial de Parques Nacionales Naturales, Governaciones de Amazonas, Caquetá, Guainia, Guaviare, Putumayo y Vaupés. Disponível em: <https://observatoriop10.cepal. org/sites/default/files/documents/stc4360-2018.pdf> Acesso em 18 set. 2020.

89 COLÔMBIA. Supremo Tribunal de Justicia. Radicación 08001-22-13-000-2019-00505-01. STC 3872-2020, 18 de junio de 2020. Luis Miguel Llorente Altamiranda versus Presidencia de la Republica de Colombia, Ministerio de Ambiente y Desarollo Sostenible, La Unidad Administrativa Especial de Parques Nacionales Naturales, la Procuraduría General de la Nación, la Fiscalía General de la Nación, la Policía Nacional y las Corporaciones Autónomas Regionales del Magdalena y Atlantico. Disponível em: <http:// files. harmonywithnatureun.org/uploads/upload953.pdf>. Acesso em: 04 set. 2020.

90 COLÔMBIA. Tribunal Superior del Distrito Judicial de Ibagué. Radicación 73001-22-00-000-2020-000091-00, 28 de agosto de 2020. Juan Felipe versus Presidencia de la Republica, Ministerio de Ambiente y Desarollo Sostenible, Autoridad Nacional de Licencias Nacionales, Ministerio de Minas y Energía, Agencia Nacional de Minería, Ministerio de Transporte, Agencia Nacional de 
reconhecendo tal condição ao rio Otún ${ }^{91}$; c) do Superior Tribunal de Medellín, reconhecendo direitos ao rio Cauca $^{92}$; d) do Terceiro Juizado de Medidas de Execução de Penas e de Medidas de Segurança, atribuindo direitos ao rio Pance ${ }^{93}$; e) do Tribunal Administrativo de Boyacá, atribuindo direitos ao Paramo de Pisba, espaço natural que integra o conjunto dos Parques Naturais Nacionais da Colômbia ${ }^{94}$; f) do Primeiro Juizado Penal de Neiva, atribuindo direitos ao rio Madalena, suas bacias e efluentes ${ }^{95}$; g) do Tribunal Administrativo de Quindío, reconhecendo ao rio de mesmo nome, sua bacia e seus afluentes, a condição de sujeito de direitos $^{96}$; g) do Juizado Civil Municipal Único de La Plata, quem atribuiu ao rio La Plata a condição de sujeito de direitos ${ }^{97}$ e; h) do Tribunal Administrativo de Tolima, reconhecendo os rios Coello, Combeima e Cocora, bem como suas bacias e afluentes como entidades individuais e como sujeitos de direitos ${ }^{98}$.

Por sua vez, a Constituição argentina também não define direitos da natureza, mas já é possível se reconhecer caminho favorável para uma abordagem ecocêntrica dos direitos, especialmente após seu tribunal superior (Suprema Corte de Justicia de la Nación), ter: a) afirmado a constitucionalidade da Lei das Geleiras ${ }^{99}$;

Infraestructura, Unidad de Parques Nacionales Naturales de Colombia, Corporación Autónoma Regional del Tolima-Cortolima, Corporación Autónoma Regional del Quindío, Coporación Autónoma Regional de Risaralda-Carder y Corporación Autónoma Regional de Caldas. Disponível em: <http://files.harmonywithnatureun.org/uploads/upload1017.pdf>. Acesso em: 04 set. 2020.

91 COLÔMBIA. Juzgado $4^{\circ}$ de Ejecución de Penas y Medidas de Seguridad. Radicación 66001318/004201900057. Sentencia de Tutela 036/2019, 11 de septiembre de 2019. John Edison Parra Sánchez y Jesús Alberto Cardona López versus Ministerio del Medio Ambiente Nacional, Departamento de Risaralda, Municipio de Pereira, Municipio de Dosquebradas, Corporación Autónoma de Risaralda-CARDE y Aguas y Aguas de Pereria. Disponível em: <http://files.harmonywithnatureun.org/uploads/upload949.pdf>. Acesso em: 04 set. 2020.

92 COLÔMBIA. Tribunal Superior de Medellín. Radicación 050013103004201900071 01. Sentencia 38/2019, 17 de junio de 2019. Juan Luis Castro Córdoba y Diego Hernán David Ochoa versus Ministerio de Ambiente y Desarrollo Sostenible, EPM, Hidroeléctrica Ituango S.A. E.S.P. y otros. Disponível em: <http://files.harmonywithnatureun.org/uploads/upload837.pdf>. Acesso em: 04 set. 2020.

93 COLÔMBIA. Juzgado Tercero de Ejecución de Penas y Medidas de Seguridad. Acción de Tutela 2019-00043-00. Sentencia 31/2019, 12 de julio de 2019. Roberto Rodríguez Zamudio versus Corporación Autónoma Regional del Valle del Cauca, Alcaldía Municipal de Cali V., Departamento Administrativo de Gestión del Medio Ambiente, Departamento Administrativo de Planeación Municipal, Empresas Municipales de Cali V., EICE ESP, las administraciones de los proyectos urbanísticos o conjuntos residenciales o condominios campestres "Reservas de Pance" y "Altos de Pance" y "JARAMILLO MORA S.A.". Disponível em: < http://files. harmonywithnatureun.org/uploads/upload948.pdf>. Acesso em: 04 set. 2020.

94 COLÔMBIA. Supremo Tribunal Administrativo de Boyacá. Radicación 152383333002201800016 01, 29 de junio de 2018. Juan Carlos Alvarado Rodríguez y otros versus Ministerio de Medio Ambiente y otros. Disponível em: < http://files.harmonywithnatureun.org/uploads/upload731.pdf>. Acesso em: 04 set. 2020.

95 COLÔMBIA. Juzgado Primero Penal del Circuito con Funciones de Conocimiento - Neiva - Huila. Radicación 41001-3109001-2019-00066-00. Sentencia de Tutela 71/2019, 24 de octubre de 2019. Andres Felipe Rojas Rodriguez y Daniel Leandro Sanz Perdomo versus Ministerio del Ambiente y Desarollo Sostenible, Autoridad Nacional de Licencias Ambientales-ANLA, Gobernacion del Huila, Aguas del Huila, Cooperación Autónoma Regional del Alto Magdalena-CAM, Empresas Publicas de Neiva, Municipios de Neiva, San Augustin, Pitalito, Saladoblanco, Oporapa, Altamira, Guadalupe, Hobo, Yagura, Aipe, Villavieja, Gigante Garzon, Paicol, Tesalia y Palermo. Disponível em: <http://files.harmonywithnatureun.org/uploads/upload869.pdf>. Acesso em: 04 set. 2020.

96 COLÔMBIA. Tribunal Administrativo de Quindío. Radicación 63001--000-2019-00024-00, 05 de diciembre de 2019. Carlos Alberto Arrieta Martínez, Luisa Fernanda León Betancourth y Juliana Victoria Ríos Quintero versus Nación-Ministerio de Vivienda, Ciudad y Territorio -, Corporación Autónoma Regional de Quindío, Municipio de Armenia, Empresas Publicas de Armenia, Municipio de Salento, Empresas Publicas del Quindío - E.P.Q, Asociación de los Suscriptores del Acueducto Rural El Rosario de la Vereda Boquía del Municipio de Salento. Disponível em: <http://files.harmonywithnatureun.org/uploads/upload997.pdf>. Acesso em: 04 set. 2020.

${ }_{97}$ COLÔMBIA. Juzgado Único Civil Municipal - La Plata - Huila. 41-396-40-03-001-2019-00114-00, 19 de marzo de 2019. Luz Marina Díaz y Otros habitantes del Barrio El Remolino de La Plata - Huila versus Empresa de Servicios Públicos del Municipio de La Plata - Huila -“EMSERPLA E.S.P.”. Disponível em: < http:// files.harmonywithnatureun.org/uploads/upload823.pdf>. Acesso em: 04 set. 2020.

98 COLÔMBIA. Tribunal Administrativo de Tolima. Radicación 73001-23-00-000-2011-00611-00, 30 de mayo de 2019. Personería Municipal de Ibagué versus Ministerio de Medio Ambiente y otros. Disponível em: <http:/ files.harmonywithnatureun.org/ uploads/upload836.pdf>. Acesso em: 04 set. 2020.

99 ARGENTINA. Corte Suprema de Justicia de la Nación. CSJ 140/2011, 4 de junio de 2019. . Barrick Exploraciones Argentinas S.A y otro versus Estado Nacional. Disponível em: <https://www.cij.gov.ar/nota-34763-La-Corte-Suprema-convalid--la-constitucionalidad-de-la-ley-de-preservaci-n-de-los-glaciares-rechazando-el-pedido-de-Barrick-Gold--Minera-Argentina-Gold-y-provinciade-San-Juan.html>. Acesso em: 04 set. 2020. 
b) afirmado um princípio in dubio pro aqua ${ }^{100}$; c) considerado uma abordagem ecocêntrica para a solução de conflitos federativos sobre o uso das águas, tendo fixado um caudal mínimo permanente para o rio Atuel ${ }^{101}$; d) e ter concedido medida cautelar em amparo coletivo para a proteção do Delta do Paraná diante de um grave contexto de incêndios sem controle e políticas públicas adequadas ${ }^{102}$.

Muitas críticas podem ser descritas sobre a direção dos direitos da natureza. Nessa ocasião, opta-se pela exposição de duas formas de compreensão sobre esse caminho.

Como é exposto por Louis Kotzé, ${ }^{103}$ o Direito precisa lidar com um modelo ético diferente. Se não é simples substituir o homem no centro das relações, já faz parte de um Direito Global aceitar que não há um centro nas relações. O homem também faz parte das relações, mas outros valores também devem fazer parte das relações.

É assim que a Constituição equatoriana não trata exclusivamente de um compromisso com a dignidade, senão, agora, com o sumak kawsay: o bem viver. A harmonia supõe o não conflito. Na harmonia não há um valor mais importante do que outro. A harmonia supõe que todos os valores são importantes. Assim, em uma comunidade de direitos, a condição humana e a natureza estão cada vez mais próximas.

Se a vida humana possui valor, a vida não humana também possui valor.

A segunda forma de compreender os direitos da natureza enfatiza que, talvez, seja necessário transformar o Direito, em alguns contextos muito graves, de massiva, sistemática e iterativa violação de realidades existenciais, ou de massivo, sistemático e iterativo descumprimento de compromissos constitucionais e convencionais associados, normalmente, à omissão, deficiência ou à inexistência de políticas públicas adequadas ${ }^{104}$.

Reconhecer direitos para a natureza talvez seja a resposta para esses contextos muito graves. Se não se consegue proteger a natureza em um modelo em que homem e natureza não são iguais, talvez nós precisemos transformar essa relação. Se homem e natureza estão cada vez mais próximos, deve-se considerar inaceitável violar as leis da natureza.

O reconhecimento de direitos e da condição de pessoa promovidos pelo parlamento neozelandês tem sua fundamentação próxima daquela justificação baseada na cosmovisão andina que orienta a definição de bem-viver utilizada pelo texto constitucional equatoriano, mas negada em grande medida pelos tribunais daquela nação latino-americana.

Na América Latina, é particularmente importante a decisão T-622 da Sexta Sala do Tribunal Constitucional Colombiano que reconheceu ao Rio Atrato, à sua bacia e aos seus efluentes “[...] como um ente sujeito de direitos à proteção, à conservação, à manutenção e à restauração ao encargo do Estado e das comunidades

\footnotetext{
100 ARGENTINA. Corte Suprema de Justicia de la Nación. CSJ 714/2016, 11 de julio de 2019. Julio Jesus Majúl versus Municipalidad de Pueblo General Belgrano y otros. Disponível em: <http://sjconsulta.csjn.gov.ar/sjconsulta/documentos/verDocumentoById.html?idDocumento $=7535693 \&$ cache $=1567286872361>$. Acesso em: 04 set. 2020 .

101 ARGENTINA. Corte Suprema de Justicia de la Nación. CSJ 243/2014, 16 de julio de 2020. Provincia de la Pampa versus Provincia de Mendoza. Disponível em: <https://www.cij.gov.ar/nota-37764-La-Corte-Suprema-fij--un-caudal-m-nimo-permanente-para-el-r-o-Atuel.html>. Acesso em: 04 set. 2020.

102 ARGENTINA. Corte Suprema de Justicia de la Nación. CSJ 468/2020, 11 de agosto de 2020. Equística Defensa del Medio Ambiente Asociación Civil versus Provincia de Santa Fe y otros. Disponível em: <https://www.cij.gov.ar/nota-38022-La-CorteSuprema-ordena-constituir-un--Comit--de-Emergencia-Ambiental--para-detener-y-controlar-los-incendios-irregulares-en-el-Deltadel-Paran-.html>. Acesso em: 04 set. 2020.

103 Cf. KOTZÉ, Louis. Global Environmental Constitutionalism in the Antrophocene. London: Hart, 2016.

104 Considerar este segundo caminho é particularmente importante neste momento em que já se divulgou no ano de 2019, o primeiro relatório sobre o Estado de Direito Ambiental, no qual se demonstrou que a proliferação da normatividade ambiental, por meio da definição de um direito fundamental ao meio ambiente, e de um direito humano ao meio ambiente, nas Constituições e nos instrumentos internacionais de proteção dos direitos humanos, não se fez suficiente para conter a expansão dos danos ambientais. UNITED NATIONS. United Nations Environmental Programme. Environmental Rule of Law. First Global Report. Nairobi: UNEP, 2019.
} 
étnicas [...]." ${ }^{105}$.

Sua importância é justificada porque se trata de uma demonstração do reconhecimento judicial, por um tribunal constitucional, da condição da natureza como sujeito, a partir de um modelo constitucional que não atribui direitos a ela, ao menos não de forma direta, como o fez o texto equatoriano. O artigo 79 da Constituição colombiana, a exemplo do artigo 225, do texto brasileiro, e do artigo 45 da Constituição espanhola parte de um arranjo que reconhece um direito ao meio ambiente, e afirma um dever estatal de protegê-lo contra ameaças. Não há na experiência colombiana, portanto, aproximação substancial com o modelo de biocentrismo declarado expressamente pelas ordens jurídicas que geralmente definem o assim denominado constitucionalismo latino-americano (Equador e Bolívia). O resultado decisório não exigiu a prévia definição normativa dos já referidos direitos da natureza.

Na sequência, pôde ser identificado o pronunciamento do dia 26 de julho de 2017, oriundo da Sala Cível do Supremo Tribunal de Justiça colombiano. Apreciando o babeas corpus AHC 4806-2017 — ação constitucional que tem por finalidade a proteção do direito de liberdade — impetrado pelo urso Chucho, em seu próprio nome, a Corte determinou sua libertação pelo zoológico de Barranquilla. ${ }^{106}$

O caso chama a atenção não só pela admissão da ação constitucional e seu resultado pelo tribunal, senão pelo contexto que a provocou. Sua origem partiu da constatação pelas autoridades de Manizalles de que não tinham mais condições de garantir a segurança, sua saúde e o seu bem-estar em seu habitat natural, a reserva de Rio Branco de Manizalles, no qual vivia há mais de duas décadas. Diante disso, a medida administrativa escolhida foi o traslado do urso para o zoológico." ${ }^{107}$

O juiz Luis Armando Tolosa Villabona considerou que não se trata de atribuir direitos aos animais não humanos, tratando-os como iguais, senão de reconhecer uma moralidade universal a partir da qual seja exigivel lhes outorgar respeito. ${ }^{108}$

Em 2018 foi emitido mais um pronunciamento colombiano, oriundo da Suprema Corte de Justiça, no qual foi apreciada pretensão de 25 crianças no âmbito de uma litigância climática, tendo sido reconhecidos direitos à floresta Amazônica e seus componentes naturais. ${ }^{109}$

De forma mais expressiva no caso Atrato, a afirmação dos direitos da natureza pode ser compreendida como a manifestação de uma solução fixada o plano de um imperativo de justiça ecológica, atribuindo-se vOz àqueles que não a possuem, visando extrair a natureza da zona invisível da ordem convencional nos sistemas de direitos onde direitos protegem interesses de pessoas naturais.

Os direitos da natureza parecem surgir no caso Atrato, também como uma estratégia discursiva de aproximação da natureza da comunidade moral que define os sistemas de direitos, supondo que, em estados de tamanha degradação sobre recursos e processos ecológicos particularmente sensíveis, a única alternativa que

\footnotetext{
105 COLÔMBIA. Corte Constitucional. Sentencia T-622/16, 10 de noviembre de 2016. Consejo Comunitario Mayor de la Organización Popular Campesina del Alto Atrato, Consejo Comunitario Mayor de la Asociación Campesina Integral del Atrato, Asociación de Consejos Comunitarios del Bajo Atrato, Foro Inter-Étnico Solidariedad Chocó y Otros versus Presidencia de la Republica y Otros. Disponível em: <https://www.corteconstitucional.gov.co/relatoria/2016/t-622-16.htm>. Acesso em 20 de jul. 2020.

106 COLÔMBIA. Corte Suprema de Justicia. Radicación 17001-22-13-000-2017-00468-02. AHC4806-2017, 26 de julio de 217. Disponível em: <http://www.cortesuprema.gov.co/corte/wp-content/uploads/relatorias/tutelas/B\%20SEP2017/AHC48062017.doc>. Acesso em 18 set. 2020.

107 COLÔMBIA. Corte Suprema de Justicia. Radicación 17001-22-13-000-2017-00468-02. AHC4806-2017, 26 de julio de 217. Disponível em: <http://www.cortesuprema.gov.co/corte/wp-content/uploads/relatorias/tutelas/B\%20SEP2017/AHC48062017.doc >. Acesso em 18 set. 2020.

108 COLÔMBIA. Corte Suprema de Justicia. Radicación 17001-22-13-000-2017-00468-02. AHC4806-2017, 26 de julio de 217. Disponível em: <http://www.cortesuprema.gov.co/corte/wp-content/uploads/relatorias/tutelas/B\%20SEP2017/AHC48062017.doc>. Acesso em 18 set. 2020.

109 COLÔMBIA. Corte Suprema de Justicia. Radicación 1101-22-03-000-2018-00319-01. STC 4360-2018, 5 de abril de 2018. Disponível em: <http://www.cortesuprema.gov.co/corte/wp-content/uploads/2018/04/STC4360-2018-2018-00319-011.pdf>. Acesso em: 18 set. 2020.
} 
poderia conter os avanços das decisões exploratórias seria situar a natureza na mesma posição moral que a condição humana. Nesse caso, em tese, maior seria a dificuldade de se produzir danos quando na relação jurídica se estivesse perante um semelhante.

Por outro lado, os direitos da natureza surgem em todas experiências descritas, como a estratégia de recomposição da relação perdida entre o homem e a Terra. Os direitos da natureza resgatam essa relação. $\mathrm{Na}$ Constituição equatoriana, v.g, mesmo se a integridade ecológica não for respeitada, a proteção será incompleta e não haverá Estado de direito.

Uma última contribuição a ser referida nesta seção tem origem na orientação firmada pela CIDH, primeiro no âmbito da opinião consultiva n. 23/2017, dada a sua contribuição interpretativa para o significado da proteção da natureza em um sistema de direitos humanos ${ }^{110}$.

Os sistemas de direitos humanos favorecem uma posição de relevância moral dos interesses da condição humana. Nessa perspectiva, até mesmos um direito humano ao meio ambiente, tal como é proposto pelo sistema global e pelos sistemas regionais, o estrutura como mais um elemento importante para que o bem-estar e a qualidade de vida estejam acessíveis às pessoas, reforçando, portanto, um sentido nitidamente antropocêntrico para os sistemas de direitos.

O reconhecimento dos efeitos e da realidade de uma possível nova época geológica (Antropoceno) também influencia transformações nas relações entre as instituições e os sistemas ecológicos, apontando a importância de inserir, nos sistemas de direitos, a natureza, indicando que, se os interesses humanos são relevantes, valores como a integridade dos sistemas ecológicos são igualmente relevantes para um sistema de direitos (humanos).

A experiência exposta pela CIDH por meio da OC n. 23/2017 demonstra a possibilidade de que o primeiro dos diversos obstáculos à valorização da natureza pelas instituições seja rompido, qual seja, incluí-la como parte desse sistema em um plano de valor tão próximo quanto seja possível daquele que é dedicado à condição humana. Se estratégias de colaboração também precisam ser estimuladas para iniciativa pelo mercado e pela sociedade, por meio de nudges ${ }^{111}$, não se deve ignorar que também devem ser favorecidas estratégias que afirmem compromissos políticos muito claros com caminhos diferentes daqueles que já foram tentados até este momento, caminhos que conduzem a outros mundos e que reafirmem a possibilidade de que um mundo melhor é possível, desde que também, antes de tudo, reconheçamos que ele exista (um mundo onde a natureza dele faz parte e é igualmente assimilada pelos sistemas de direitos).

Nesse sentido, se a jurisprudência latino-americana já sinalizava o fortalecimento de uma dimensão ecocêntrica para os sistemas de direitos, tal como foi reconhecido pela Colômbia em três ocasiões (Chucho, Atrato e Amazônia), o pronunciamento da CIDH por meio de tal opinião consultiva confirma sua aderência ao modo como, no sistema interamericano, deve ser definido o conteúdo de um direito humano ao meio ambiente.

Se, por um lado, a condição humana deixou de ser indispensável para justificar a proteção de direitos, por outro lado, a definição do conteúdo desses direitos (para além da justificação da proteção, portanto) também foi potencializada pelo alargamento moral da comunidade de direitos no âmbito do sistema interamericano de direitos humanos (SIDH).

\footnotetext{
110 COSTA RICA. Corte Interamericana de Derechos Humanos. Opinion consultiva OC-23/17, de 15 de noviembre de 2017. Disponível em: <http://www.corteidh.or.cr/docs/opiniones/seriea_23_esp.pdf >. Acesso em: 02 set. 2020. Posteriormente, a decisão também foi expressamente utilizada pela mesma Corte Interamericana de Direitos Humanos, influenciou uma abordagem ecocêntrica sobre os direitos, no caso Comunidades Indígenas Miembros de la Asociación Lhaka Honhat (Nuestra Tierra) versus Argentina. Cf.: COSTA RICA. Corte Interamericana de Derechos Humanos. "Caso comunidades indígenas miembros de la asociación Lhaka Honhat (nuestra tierra) versus Argentina” (fondo, reparaciones y costas), sentencia 6 de febrero de 2020. Disponível em: <https://www.corteidh.or.cr/docs/casos/articulos/seriec_400_esp.pdf>. Acesso em: 04 set. 2020.

111 A expressão é utilizada em seu exato sentido proposto por Sunstein e Thaler, na forma de um paternalismo libertário, em: SUNSTEIN, Cass; THALER, Richard. Nudge: Improving Decisions about Health, Wealth and Happiness. Yale University Press, 2008.
} 
Portanto, ao menos no SIDH, para o fim de se compreender um sistema de direitos e uma comunidade de justiça, o que proteger e quem proteger significa um passo adiante das fronteiras tradicionais da justiça intraespécies e intrageracional.

Desse modo, a natureza faz parte de uma comunidade de justiça, a natureza tem valor para o fim de proteção em um sistema de direitos, e os direitos humanos são também humanos.

Constam das razões do acórdão que o tribunal:

[...] considera importante ressaltar que o direito ao meio ambiente sadio como direito autônomo, diferente de outros direitos, protege os componentes do meio ambiente, tais como bosques, rios, mares e outros, como interesses jurídicos em si mesmos, ainda que na ausência de certeza ou evidência sobre o perigo a indivíduos. Trata-se de proteger a natureza e o meio ambiente não somente por sua conexão com uma utilidade para o ser humano ou pelos efeitos que sua degradação poderia causar em outros direitos das pessoas, como a saúde, a vida ou a integridade pessoal, senão por sua importância para os demais organismos vivos com os quais se compartilha o planeta, também merecedores de proteção em si mesmos. Nesse sentido, o tribunal adverte uma tendência a reconhecer personalidade jurídica e, portanto, direitos a natureza não somente em sentenças senão também em ordenamentos constitucionais.

Desta maneira, o direito a um meio ambiente sadio como direito autônomo é distinto do conteúdo ambiental que surge da proteção de outros direitos, tais como o direito à vida ou o direito à integridade pessoal." ${ }^{\prime 12}$

$\mathrm{Na}$ medida em que o Brasil está submetido à jurisdição da Corte desde 1998 (decreto legislativo n. 89/1986 e aceitou o resultado de sua iniciativa consultiva desde a ratificação da Convenção Americana de Direitos Humanos, em 25 de setembro de 1992, não é possível atribuir outro conteúdo a um direito humano ao meio ambiente ou negar a aplicação do conteúdo que foi definido pela Corte, no âmbito interamericano. Se por um lado as decisões emanadas da Corte em sua atuação consultiva vinculam a própria Corte sobre como deve ser a interpretação dos direitos humanos enunciados na Convenção, por outro lado, não é possível que os Estados submetidos à sua jurisdição desatendam às suas decisões, nos termos do que se encontra definido pelo artigo 68-1, da CADH.

Se, em um primeiro momento, experiências como a colombiana poderiam se apresentar como uma manifestação de ativismo necessário para o fim de suprir lacunas da ausência de decisões satisfatórias pelo Poder Legislativo ou Executivo, e para o fim suprir as falhas públicas e privadas na proteção da natureza (atuando aqui como um superego da sociedade), nesse momento tais manifestações são confirmadas pela Corte como evidências não para o caminho correto, ou para o melhor caminho na proteção da natureza. Tais decisões são confirmadas como evidências de que outro caminho é possível, e que esse outro caminho é coerente com aquele que a CIDH definiu a partir da OC n. 23/2017, como aquele que deve guiar a interpretação do direito humano ao meio ambiente.

Assim, se o processo de ecologização foi iniciado pelos Estados-parte em um sentido de estímulo para a ordem internacional, a iniciativa da CIDH não apenas fortalece aquelas iniciativas, senão aponta a direção na ordem interamericana, sobre muito mais do que uma autorização, senão um dever ao qual estão sujeitos

112 COSTA RICA. Corte Interamericana de Derechos Humanos. Opinion consultiva OC-23/17, de 15 de noviembre de 2017. Disponível em: <http://www.corteidh.or.cr/docs/opiniones/seriea_23_esp.pdf>. Acesso em: 02 set. 2020. Lê-se no original: “62. Esta Corte considera importante resaltar que el derecho al medio ambiente sano como derecho autónomo, a diferencia de otros derechos, protege los componentes del medio ambiente, tales como bosques, ríos, mares y otros, como intereses jurídicos en sí mismos, aún en ausencia de certeza o evidencia sobre el riesgo a las personas individuales. Se trata de proteger la naturaleza y el medio ambiente no solamente por su conexidad con una utilidad para el ser humano o por los efectos que su degradación podría causar en otros derechos de las personas, como la salud, la vida o la integridad personal, sino por su importancia para los demás organismos vivos con quienes se comparte el planeta, también merecedores de protección en sí mismos. En este sentido, la Corte advierte una tendencia a reconocer personería jurídica y, por ende, derechos a la naturaleza no solo en sentencias judiciales sino incluso en ordenamientos constitucionales. 63. De esta manera, el derecho a un medio ambiente sano como derecho autónomo es distinto al contenido ambiental que surge de la protección de otros derechos, tales como el derecho a la vida o el derecho a la integridad personal." 
todos os Estados-parte, de interpretar os direitos humanos com base em um sentido ecológico.

Direitos humanos protegem a condição humana e o Antropoceno coloca em evidência que esse modelo é frágil e precisa de estratégias para inserir a natureza dentro daquele sistema de direitos.

$\mathrm{Na}$ abordagem interpretativa fixada pela CIDH, por meio de sua OC n. 23/2017, os direitos humanos admitem a valorização de outros aspectos morais, fixando-se que direitos humanos não estabelecem compromissos exclusivos com a condição humana.

Se fosse possível extrair três grandes contribuições emergentes da OC n. 23/2017 poderiam ser destacadas: a) o reconhecimento de direitos humanos autenticamente ambientais na medida em que se admitiu a exposição de violações independente do uso dos direitos originariamente descritos na Convenção Americana; b) a função vinculativa de sua decisão para a interpretação do direito humano ao meio ambiente e; c) o reconhecimento de que para além da condição humana, a natureza também faz parte do sistema de direitos, ainda que este sistema de direitos seja, ainda, e aporeticamente, um sistema de direitos humanos.

Experiências normativas e culturais tão distintas como aquelas representadas pela brasileira, a colombiana, e a equatoriana, veem-se aproximadas em torno de objetivos comuns, não porque se tratam de experiências que deram certo, ou porque são objeto de consensos internacionais (há muito mais tratados internacionais que protegem o ambiente do que Constituições, embora estas também se apresentem em número expressivo). Estão unidas como parte dos diálogos normativos que se veem estimulados em uma sociedade cosmopolita, por um modelo de constitucionalismo que não consegue proteger os bens que, de fato, são importantes em tal sociedade, a não ser mediante a abertura dessa comunidade moral, integrando de forma plena e completa, todos os interesses, as necessidades e as demandas de proteção em expansão.

$\mathrm{Na}$ sociedade que é global e cosmopolita, as fontes de normatividade estão difusas e fragmentadas ${ }^{113}$, cumpre à Constituição assumir a relevante função de mediação e de interligação de tais fragmentos na tentativa de formação do que Gunter Teubner chama de direito constitucional de colisões. ${ }^{114}$

Se a produção normativa é fragmentária, cumpre às Constituições a função de mediação e de ligação desses fragmentos no sentido de proporcionar que os distintos pontos de vista e modelos culturais e sociais consigam dialogar em torno de objetivos comuns, que neste caso, referem-se à proteção da natureza.

Mais do que uma comunidade de direitos em expansão, assiste-se à emergência e ao fortalecimento de uma comunidade de deveres perante valores de uma sociedade global e cosmopolita.

A consideração de um assim denominado Direito (e de um constitucionalismo) cosmopolita é exposta como uma premissa indispensável para a justificação de um assim denominado Estado de Direito para a natureza. Nesse modelo de Estado, proteger e respeitar o pluralismo de objetivos morais que definem uma sociedade cosmopolita exigiria uma transformação de como as relações jurídicas entre homem e natureza são organizadas pelas Constituições.

A coexistência entre as formas de vida e a não intervenção sobre os processos ecológicos são expostos como desafios para a consideração jurídica dos modelos constitucionais ocidentais, e como metas para a transformação dos sistemas de valores protegidos pelo Direito.

É nesse sentido que se pode argumentar que a proposição de padrões de decisão que favoreçam a natureza constitui, antes de tudo, um imperativo de justiça ecológica. Entretanto, é pertinente que se compreenda em que consiste favorecer padrões de justiça ecológica por meio de se favorecer a proteção da natureza.

Uma primeira leitura sobre o padrão de decisão de um assim denominado princípio in dubio pro natura

113 LADEUR, Karl-Heinz. A relação entre direito público e normas sociais no constitucionalismo - nacional, europeu e global. Direito UnB, v. 2, p. 17, jan./abr. 2016.

114 TEUBNER, Gunter. Fragmentos constitucionais. Constitucionalismo social na globalização. Trad. de: Marcelo Neves, Pedro Ribeiro, Ricardo Campo, Rodrigo Mendes. São Paulo: Saraiva, 2016. p. 44. 
prioriza um modelo de escolha para remover o obstáculo da dúvida. É o estado de dúvida que exige um modelo de decisão, que deve ser uma decisão em favor da natureza. Esse elemento (dúvida) o aproxima do padrão de decisão adotado por outro princípio com reconhecimento internacional e nacional, no contexto brasileiro, um princípio de precaução. Neste último, a incerteza científica (ou a ausência de consenso científico) não pode justificar a ausência de decisão.

O que se tem na incerteza científica é normalmente a divergência, havendo, portanto, repostas certas, mas diversas respostas certas. E, igualmente, em situações limites caracterizadas pela inovação, a ausência de conhecimento (portanto, a dúvida científica) define que não se poderá aguardar a adoção de medidas ${ }^{115}$. Distintamente de um princípio in dubio pro natura, neste há uma preponderância de um caráter procedimental, não se propondo ou definindo, prima facie, que medidas serão essas ou qual é a extensão das ações que será demandada perante a ameaça e o risco. O padrão de decisão do primeiro princípio é diferenciado porque há uma ordem e um mandado para que as medidas deverão beneficiar e favorecer a natureza e sua proteção.

Não se pode compreender o princípio, entretanto, como um mandado de proteção para a natureza apenas na dúvida, ou como um mandado de proteção exclusiva da natureza em superposição de outras demandas de justiça.

Deve-se, primeiramente, reiterar que justiça ecológica é um padrão de justiça que se pretende completo e integral, porque deve ser capaz de propor respostas ou soluções para conflitos no sentido de acolher ou atender as demandas de todos os interessados e beneficiários de uma comunidade de justiça: a comunidade humana, as futuras gerações e a comunidade não humana (animais não humanos e natureza).

Portanto, imperativos pro natura são passíveis de se justificar sempre que se estiver em jogo o comprometimento da integridade dos sistemas naturais e dos processos ecológicos. Desse modo, o conteúdo de um princípio in dubio pro natura pode ser melhor justificado no contexto de uma virada ecológica dos direitos, devendo haver uma decisão em favor da natureza sempre que se fizer exigível devolver a natureza ao seu lugar, de natureza. A exemplo do que foi posicionado pela Suprema Corte de Justicia de La Nación mexicana, o princípio in dubio pro natura não é aplicável somente perante a incerteza científica, senão como mandado interpretativo geral de justiça ambiental, no sentido de que em qualquer conflito ambiental deve prevalecer, sempre, aquela interpretação que favoreça a conservação do meio ambiente ${ }^{116}$.

\section{Consoante Susana Borrás:}

“ao contrário do princípio in dubio pro reo, típico do direito penal, o princípio in dubio pro natura não é uma regra operacional, para que o juiz decida quando houver dúvida. O princípio in dubio pro natura determina que a interpretação da lei deve favorecer uma das partes. É um verdadeiro mecanismo de repressão e contingência para os casos em que várias decisões seriam juridicamente possíveis, apesar de nem todas serem convenientes à luz de uma política ambiental específica.". ${ }^{117}$

\footnotetext{
115 Esse sentido é aquele que se encontra reproduzido no princípio 10, da Declaração do Rio sobre Meio Ambiente e Desenvolvimento, de 1992. (UNITED NATIONS. Rio Declaration on Environment and Development. Disponível em: <https://www.un.org/ en/development/desa/population/migration/generalassembly/docs/globalcompact/A_CONF.151_26_v. I_Declaration.pdf>. Acesso em: 12 jul. 2020).

116 MEXICO. Suprema Corte de Justicia de la Nación. Amparo en Revisión 307/2016, Sentencia de 14 de noviembre de 2018. Disponível em: <https://www.scjn.gob.mx/sites/default/files/listas/documento_dos/2018-11/AR-307-2016-181107.pdf>. Acesso em: 10 set. 2020. Lê-se no destaque original, extraído da decisão: "Esta Sala entiende el principio in dubio pro natura no sóloacotado al principio de precaución, esto es, no sólo aplicable anteincertidumbre científica, sino como mandato interpretativo generalde la justicia ambiental, en el sentido de que en cualquier conflictoambiental debe prevalecer, siempre, aquella interpretación que favorezca la conservación del medio ambiente.". O sentido é, portanto, bastante distinto de se decidir em favor da natureza, apenas nos casos de dúvida interpretativa, ou ainda, de se ponderar os valores em conflito para se decidir em favor da natureza. Trata-se, portanto, de se sempre se procurar alcançar o melhor sentido que favoreça a natureza em todos os conflitos em matéria ambiental. O segundo sentido encontra-se desenvolvido em: ALCÂNTARA, Maria Isabel Esteves de Alcântara; BALBINO, Michelle Lucas Cardoso. A Ponderação como Mecanismo de Solução de Conflitos entre Princípios Norteadores do Direito Penal Ambiental, Revista Brasileira de Políticas Públicas, v. 4, n. 1, p. 256-271, 2014.

117 BORRÁS, Susana. In dubio pro natura:un principio transformador del derecho ambiental en América Latina. In: MIRANDA, Jorge; AMADO GOMES, Carla; PENTINAT, Susana Borrás. Diálogo Ambiental, Constitucional e Internacional. Rio de Janeiro: Lumen
} 
O giro ecológico na jurisprudência dos tribunais relacionados nesta seção favorece a compreensão de que o fortalecimento de narrativas constitucionais que respeitem a integridade dos sistemas naturais e dos processos ecológicos colabora não apenas para se justificar escolhas pro natura, senão para ampliar o próprio conteúdo do princípio in dubio pro natura.

De todo o exposto foi possível demonstrar que uma proteção jurídica que favoreça a natureza não se satisfaz, privilegiando-se a aplicação de novos princípios ou por meio de sua mera transposição entre sistemas jurídicos distintos. A afirmação de uma abordagem ecológica para direitos encontra-se em expansão — tal qual se encontra refletido na jurisprudência já referida — e nela se localiza, possivelmente, uma das melhores oportunidades de se justificar que há limites ecológicos dos sistemas naturais que não podem ser ignorados pelos sistemas de direitos, exigindo-se, portanto, escolhas e decisões pro natura.

Embora não seja possível afirmar que a ordem constitucional brasileira acolha textualmente um abordagem que reconheça, a exemplo do texto equatoriano já referido neste trabalho, a condição de um sujeito natural, não é possível ignorar que, em pelo menos três oportunidades, o Supremo Tribunal Federal (STF) sinalizou uma tendência convergente com a virada ecológica em curso no contexto das experiências jurídicas latino-americanas ${ }^{118}$, na medida em que o ministro Ricardo Lewandowski externou ser possível o reconhecimento de uma dimensão ecológica para a dignidade da vida.

A transformação ecológica dos direitos é o contexto no qual se insere um mandado in dubio pro natura, o qual se encontra pela ordem constitucional brasileira, conforme já se demonstrou anteriormente.

Conforme já se argumentou por meio da proposição de Corine Pelluchon, reparar o mundo é, antes de tudo, e justamente, devolver a natureza ao seu lugar, de naturez̧a. Por essa razão, decisões em favor da natureza devem refletir, antes de tudo, compromissos reais do Direito e dos sistemas de direitos, para com os sistemas naturais e os processos ecológicos, supondo-se — conforme é ilustrado pelo conhecimento científico disponível — que a condição humana depende, necessariamente, da manutenção da integridade daqueles (sistemas naturais e processos ecológicos), não sendo possível ou razoável justificar-se, nesse momento, a manutenção e o fortalecimento de abordagens jurídicas que restrinjam e limitem o lugar da natureza nos sistemas de direitos.

Não é por outra razão que, neste momento é ainda mais poderosa e, ao mesmo tempo, realista a mensagem que foi compartilhada por Gomes Canotilho há vinte e cinco anos:

o direito deveria, de acordo com as suas posses, assumir a responsabilidade pela defesa da vida na terra - e não apenas do homem. Para os fundamentalistas ecológicos seria de olhar com desconfiança para os juristas, mesmo para os juristas com alguma consciência ecológica. Estes não conseguem abandonar, não obstante as suas juras ambientais, omito de Adão fora do paraíso. Os perigos estariam à vista: quando os juristas se interessam pelo ambiente deveremos estar sempre de vigília, pois existirá sempre o risco de, em vez de se conseguir a ecologização do direito, se terminar encapuçadamente na juridicização da ecologia. Daí as propostas e desafios fractais das correntes ecológica-quimicamente puras: só uma visão ecocêntrica - a defesa da vida, a salvação do planeta terra - constituirá um ponto de partida satisfatório para um direito do ambiente ecologicamente amigo. Os desafios aí estão: para

\footnotetext{
Juris, 2018. p. 16. Lê-se no original: A diferencia del principio in dubio pro reo, propio del Derecho penal, el principio in dubio pro natura no es una regla operativa, para que el juez pueda decidir cuando exista una duda. El principio in dubio pro natura determina que la interpretación del derecho debe favorecer una de las partes. Se trata e un verdadero mecanismo de represión y de contingencia para los casos en que varias decisiones serian jurídicamente posibles, a pesar de que no todas son convenientes a la luz de una determinada política ambiental."

118 BRASIL. Supremo Tribunal Federal. ADPF 658 MC, 22 de junho de 2020. Diário da Justiça, DF, 31 agos. 2020. Disponível em: < http://portal.stf.jus.br/> Acesso em: 15 set. 2020; BRASIL. Supremo Tribunal Federal. ADPF 656 MC, 22 de junho de 2020. Diário da Justiça, DF, 31 agos. 2020. Disponível em: < http://portal.stf.jus.br/ > Acesso em: 15 set. 2020; BRASIL. Supremo Tribunal Federal. ADI 4.983, 06 de outubro de 2016. Diário da Justiça, DF, 27 abr. 2017. Disponível em: < http://portal.stf.jus.br/> Acesso em: 15 set. 2020. No STJ a afirmação argumentativa de uma dimensão ecológica da dignidade da vida foi externada pelo min. Og Fernandes em: BRASIL. Superior Tribunal de Justiça. REsp 1797175/SP. Recurso Especial 2018/0031230-0, 21 de março de 2019. Diário da Justiça, DF, 28 mar. 2019. Disponível em: <https://www.stj.jus.br/>. Acesso em: 05 jul. 2020.
} 
quando um sistema jurídico reconhecedor de direitos fundamentais da natureza? Enquando não se consagrarem, em termos jurídicos, direitos dos animais e direitos das plantas - direitos dos seres vivos ao lado dos direitos do homem, os ecologistas continuam a olhar para o direito do ambiente como a expressão mais refinada da razão cínica. ${ }^{119}$

Um constitucionalismo que se propõe viabilizar, simultaneamente, as condições básicas de uma vida decente ${ }^{120}$, e que se comprometa com a vida, supõe a consideração de uma principiologia que favoreça a integração dos dois objetivos definidores, por um lado, de compromissos com a pessoa humana (dignidade), e de outro lado, compromissos ecológicos (integridade dos processos ecológicos), como partes de um agora, único projeto constitucional, comprometido com a pluralidade característica de sociedades cosmopolitas, nas quais os dois mundos, humano e não humano, fazem parte de uma mesma comunidade de justiça.

\section{Considerações finais}

Por meio de revisão bibliográfica, de uma abordagem que optou pela consideração da ordem constitucional brasileira, e de pesquisa jurisprudencial em tribunais superiores do Brasil, do México, do Equador, da Argentina e da Colômbia, foi possível demonstrar que, no contexto em que já se reconheceram as limitações de uma abordagem definidora de direitos, a proteção jurídica da natureza depende, neste momento, da consideração de estratégias em sistemas jurídicos que sejam capazes de favorecer decisões em favor da natureza.

O princípio in dubio pro natura, originalmente acolhido de forma textual no artigo 395.4, da Constituição do Equador, prevê que, nos casos de dúvidas sobre o alcance das disposições legais em matéria ambiental, elas devem ser aplicadas no sentido que seja mais favorável à proteção da natureza.

Embora o princípio - que também estabelece relações com um princípio de precaução — dirija, materialmente, o conteúdo das respostas para conflitos socioambientais, nos casos em que existam dúvidas sobre como as normas devem ser aplicadas, deve-se enfatizar que o conteúdo do princípio deve ser adequadamente compreendido no contexto de um Direito ambiental que se encontra em transformação.

Reconhecer a existência de um mundo em transformação e que o Direito é uma forma de interpretar esse mesmo mundo, também implica que se considere as transformações experimentadas pelo Direito para o fim de interpretar e compreendê-lo.

Em um mundo que foi desafiado por duas emergências globais simultâneas (pandemia virótica e as mudanças climáticas globais), a ciência tem ocupado função de relevância, ao menos para se demonstrar que existe uma relação de dependência necessária entre as necessidades humanas e os sistemas naturais. A ciência demonstrou no contexto desses dois eventos/emergências planetárias, que um imperativo ecológico é demonstrável e não mais se encontra sujeito à incerteza.

Sob a perspectiva da demonstração de tal dependência entre os sistemas naturais e o mundo humano, permitiu-se justificar a aderência de uma transformação sobre como o Direito se relaciona com os sistemas naturais. Essa realidade de transformação permitiu reconhecer a expansão de um Direito com compromissos com a natureza, um Direito ecológico, e de sistemas de direitos que priorizassem uma abordagem ecológica para direitos.

A transformação ecológica do Direito se insere no contexto da própria transformação do mundo, dizendo respeito, portanto a como este mundo é interpretado pelo Direito.

\footnotetext{
119 CANOTILHO, José Joaquim Gomes. Direito do Ambiente e crítica da razão cínica das normas jurídicas. Revista de Direito do Ambiente e Ordenamento do Território,. n. 1, p. 98, Set. 1995.

120 O sentido de vida decente é o de: MARGALIT, Avishai. La sociedad decente. Barcelona: Paidos, 1997. Por sociedade decente entende-se aquela na qual as instituições não submetem as pessoas a estados humilhantes ou depreciativas.
} 
Essa transformação reforça uma premissa de que o Direito ecológico — compreendido aqui como o modo como o Direito, neste momento, pode interpretar o mundo - é o resultado possível no sentido de refletir uma aproximação entre o Direito e os sistemas naturais. Essa aproximação é possível neste momento, considerando-se o estado do conhecimento científico disponível, por meio da ciência.

Nesse sentido, a consideração da ciência do sistema terrestre — aqui identificada pelos estudos relativos ao espaço operacional seguro e pelos limites planetários - pode favorecer uma ordem jurídica que se fundamenta na importância da natureza e no reconhecimento das realidades dos sistemas ecológicos, por meio da consideração de um direito ecologicamente sensibilizado.

Desse modo, foi possível determinar que um Direito que se diga ecológico não pode, em primeiro lugar, frustrar as leis da natureza.

No âmbito de um Direito que tem de compreender e interpretar um mundo em transformação, o trabalho justificou que, a partir da ordem constitucional brasileira, o texto do artigo $225, \int 1^{\circ}$, e seus incisos I e VII representa uma clara manifestação de aproximação do Direito com os sistemas naturais. Essa aproximação reflete um diálogo entre Direito e ciência na medida em que o texto constitucional expressa, por meio de deveres estatais de proteção cujo conteúdo se adstringe a obstar todas as escolhas e decisões que não respeitem a integridade dos processos ecológicos essenciais e dos sistemas naturais.

Uma vez que é demonstrável na ordem constitucional brasileira a existência de uma estrutura institucional (normativa) de um Direito que possui compromissos com os sistemas naturais e os processos ecológicos, considerou-se que é possível justificar-se um imperativo de in dubio pro natura que não se restringe a contextos de dúvida, ou a contextos de resolução de conflitos restritos a hipóteses de dúvida.

A aproximação do Direito com os sistemas naturais — proporcionada pelo acolhimento de definições científicas relevantes pelos sistemas jurídicos, como as de limites planetários (ou fronteiras planetárias), de ponto de inflexão e de espaço operacional seguro - permite, no contexto da ordem constitucional brasileira, justificar que decisões em favor da natureza não têm origem apenas em contextos de conflitos ou em contextos de limitações cognitivas ou de incerteza científica.

Em uma realidade normativa assim caracterizada, um mandado in dubio pro natura somente pode ser adequadamente compreendido se a Constituição (ecológica) for levada a sério. Os compromissos estatais e sociais definidos pelo artigo 225 para com os sistemas naturais e os processos ecológicos implicam que, não só nas hipóteses de conflitos permeados pela incerteza, ou nos casos de dúvida interpretativa, ou ainda, nos casos de insuficiência informativa, deve-se fazer uma escolha em favor ou tomar-se uma decisão que favoreça a natureza.

Considerando-se que a biodiversidade é um dos limites ou fronteiras do Planeta, sempre que se estiver perante ações, atos, processos ou quaisquer iniciativas que tenham aptidão de rompê-lo, será exigível uma decisão ou uma escolha em favor da natureza.

Essa perspectiva - construída a partir da realidade constitucional brasileira - encontra-se reforçada na jurisprudência de tribunais selecionados neste trabalho (Argentina, Brasil, Colômbia e México), por meio da qual foi possível demonstrar que justificar respostas que favoreçam a natureza depende, primordialmente, de se assegurar o atendimento de deveres de se respeitar os limites planetários, pelos sistemas jurídicos. Trata-se do objetivo que se encontra designado a um Direito ecológico, sendo este um sistema que coordena regras e princípios comprometidos com a integridade dos sistemas naturais e os processos ecológicos.

É assim que se pôde demonstrar que a afirmação de compromissos ecológicos que se encontram definidos pelas Constituições - em distintos níveis que alcançariam, desde a manutenção da integridade dos sistemas ecológicos, e até mesmo a subjetivação da natureza — é indispensável para que se justifiquem decisões e escolhas pro natura.

Por meio do reconhecimento de que sistemas jurídicos devem respeitar os limites planetários e os limites 
ecológicos dos sistemas naturais, foi possível demonstrar que uma proteção jurídica que favoreça a natureza também estaria melhor justificada em um conteúdo ampliado que agora pode ser designado ao princípio in dubio pro natura, tal como foi expressamente reconhecido pela Suprema Corte de Justicia de la Nación mexicana, v.g, em sua decisão 307/2016.

É nesse sentido que se concluiu que favorecer a proteção jurídica da natureza não pode se limitar ao resultado de uma aplicação restritiva de um assim denominado princípio in dubio pro natura, em seu sentido transposto do texto constitucional equatoriano.

No lugar de se privilegiar a aplicação literal de seu significado, e de se favorecer um mandado de na dúvida se deve proteger a natureza, enfatiza-se um mandado geral de aplicação do sentido das normas jurídicas que melhor favoreça a natureza.

Trata-se, a exemplo do que foi definido pela Suprema Corte de Justicia de La Nación mexicana, em sua decisão 307/2016, de um mandado interpretativo geral de justiça ambiental, por meio do qual, em qualquer controvérsia sobre tema ambiental se deve buscar aquela interpretação que favoreça a proteção da natureza.

Desse modo, duas foram as perspectivas de fragilização (weak approach) que foram refutadas neste trabalho. Pela primeira delas, tem-se que a dúvida não pode ser considerada uma condição para justificar escolhas ou decisões em favor da natureza. Da mesma forma, não se pode considerar a hipertrofia do conteúdo de um princípio in dubio pro natura para justificar realidades de totalitarismo ecológico no qual o valor da natureza substituiria os valores e compromissos com a condição humana.

Ainda que exista, no contexto nacional, um conjunto de consequências jurídicas já extraídas de um princípio in dubio pro natura, por meio da jurisprudência do STJ, levar a sério a Constituição ecológica brasileira implica reconhecer que há imperativos jurídicos de não se comprometer a integridade dos sistemas naturais e dos processos ecológicos, exigindo-se, sempre que se estiver perante semelhante realidade, uma decisão em favor da natureza.

O giro ecológico na jurisprudência dos tribunais descritos na última seção favoreceu a compreensão de que narrativas constitucionais comprometidas com a integridade dos sistemas naturais favorecem uma abordagem de ampliação do conteúdo de um princípio in dubio pro natura.

É, portanto, no contexto de um sistema de direitos que favorece a proteção da natureza mediante uma abordagem que aproximeo Direito dos sistemas naturais, que se deve compreender o conteúdo de um princípio in dubio pro natura. A proposição se encontra em sintonia com a direção que foi confirmada pela jurisprudência dos tribunais nacionais, latino-americanos, e no sistema regional de direitos humanos, pela OC n. 12/2017, da CIDH.

O estado do conhecimento científico disponível demonstrou a fragilidade de modelos jurídicos meramente definidores de direitos, e também demonstrou a dependência do gozo e do exercício dos direitos humanos, dos sistemas naturais e dos processos ecológicos.

Embora seja possível (e necessário) justificar decisões em favor da natureza nos casos de dúvida e de incerteza científica, já se chegou ao momento de emergência em que decisões em favor da natureza se encontram justificadas por níveis cada vez maiores de ciência.

Também já se chegou ao momento em que a transformação ecológica dos sistemas de direitos decorre de fórmulas jurídicas que acolhem cada vez mais fortemente, imperativos ecológicos de decisão.

Sendo assim, em uma realidade em que a função do Direito se expande para concretizar dimensões ecológicas de direitos, pode-se concluir não ser possível restringir a justificação de decisões pro natura como o resultado exclusivo de modelos de soluções para contextos de dúvida interpretativa sobre normas jurídicas. 


\section{Referências}

ALCÂNTARA, Maria Isabel Esteves de Alcântara; BALBINO, Michelle Lucas Cardoso. A Ponderação como Mecanismo de Solução de Conflitos entre Princípios Norteadores do Direito Penal Ambiental, Revista Brasileira de Politicas Públicas, v. 4, n. 1, p. 256-271, 2014.

ARGENTINA. Corte Suprema de Justicia de la Nación. CSJ 140/2011, 4 de junio de 2019. . Barrick Exploraciones Argentinas S.A y otro versus Estado Nacional. Disponível em: <https://www.cij.gov.ar/ nota-34763-La-Corte-Suprema-convalid--la-constitucionalidad-de-la-ley-de-preservaci-n-de-los-glaciares-rechazando-el-pedido-de-Barrick-Gold--Minera-Argentina-Gold-y-provincia-de-San-Juan.html>. Acesso em: 04 set. 2020.

ARGENTINA. Corte Suprema de Justicia de la Nación. CSJ 714/2016, 11 de julio de 2019. Julio Jesus Majúl versus Municipalidad de Pueblo General Belgrano y otros. Disponível em: < http://sjconsulta.csjn.gov. ar $/$ sjconsulta $/$ documentos $/$ verDocumentoById.html?idDocumento $=7535693 \& \mathrm{cache}=1567286872361>$. Acesso em: 04 set. 2020.

ARGENTINA. Corte Suprema de Justicia de la Nación. CSJ 243/2014, 16 de julio de 2020. Provincia de la Pampa versus Provincia de Mendoza. Disponível em: < https://www.cij.gov.ar/nota-37764-La-Corte-Suprema-fij--un-caudal-m-nimo-permanente-para-el-r-o-Atuel.html>. Acesso em: 04 set. 2020.

ARGENTINA. Corte Suprema de Justicia de la Nación. CSJ 468/2020, 11 de agosto de 2020. Equística Defensa del Medio Ambiente Asociación Civil versus Provincia de Santa Fe y otros. Disponível em: <https:// www.cij.gov.ar/nota-38022-La-Corte-Suprema-ordena-constituir-un--Comit--de-Emergencia-Ambiental--para-detener-y-controlar-los-incendios-irregulares-en-el-Delta-del-Paran-.html>. Acesso em: 04 set. 2020.

AYALA, Patryck de Araújo. Constitucionalismo global ambiental e os direitos da natureza. In: LEITE, José Rubens Morato; AYALA, Patryck de Araujo; CAPDEVILLE, Fernanda Cavedon; MELO, Melissa Ely; SILVEIRA, Paula Galbiatti; DAROS, Leatrice Faraco. A Ecologização do Direito Ambiental Vigente: Rupturas Necessárias. Rio de Janeiro: Editora Lumen Juris, 2018. p. 145-184.

BENJAMIN, Antonio Herman. Constitucionalização do ambiente e ecologização da constituição brasileira. In. CANOTILHO, José Joaquim Gomes \& LEITE, José Rubens Morato (Org.). Direito constitucional ambiental brasileiro. 5. ed. São Paulo: Saraiva, 2012.

BORRÁS, Susana. In dubio pro natura:un principio transformador del derecho ambiental en América Latina. In: MIRANDA, Jorge; AMADO GOMES, Carla; PENTINAT, Susana Borrás. Diálogo Ambiental, Constitucional e Internacional. Rio de Janeiro: Lumen Juris, 2018. p. 5-40.

BRASIL. Supremo Tribunal Federal. ADPF 658 MC, 22 de junho de 2020. Diário da Justiça, DF, 31 agos. 2020. Disponível em: < http://portal.stf.jus.br/> Acesso em: 15 set. 2020.

BRASIL. Supremo Tribunal Federal. ADPF 656 MC, 22 de junho de 2020. Diário da Justiça, DF, 31 agos. 2020. Disponível em: <http://portal.stf.jus.br/ > Acesso em: 15 set. 2020.

BRASIL. Supremo Tribunal Federal. ADI 4.983, 06 de outubro de 2016. Diário da Justiça, DF, 27 abr. 2017. Disponível em: < http://portal.stf.jus.br/> Acesso em: 15 set. 2020.

BRASIL. Supremo Tribunal Federal. Audiodescrição. Audiências Públicas do STF, Fundo do Clima, 4ª Parte, 25 de setembro de 2020 Disponível em: <https://www.youtube.com/watch?v=uK5hNV-NDY0>.Acesso em: 25 set. 2020.

BRASIL. Superior Tribunal de Justiça. REsp 1797175/SP. Recurso Especial 2018/0031230-0, 21 de março de 2019. Diário da Justiça, DF, 28 mar. 2019. Disponível em: <https://www.stj.jus.br/>. Acesso em: 05 jul. 2020. 
BRASIL. Superior Tribunal de Justiça. Jurisprudência em Teses. Disponível em: < http:/ /www.sti.jus.br/SCON/ jt/toc.jsp>. Acesso em 02 jul. 2020.

BRASIL. Superior Tribunal de Justiça. REsp 1668652/PA. Recurso Especial 2017/0086149-3, 27 de novembro de 2018. Diário da Justiça, DF, 08 fev. 2019. Disponível em: <http://www.stj.jus.br/>. Acesso em: 02 jul. 2020.

BRASIL. Superior Tribunal de Justiça. REsp 1356207/SP. Recurso Especial 2012/0251709-6, 28 de abril de 2015. Diário da Justiça, DF, 07 mai. 2015. Disponível em: <http://www.sti.jus.br/>. Acesso em: 02 jul. 2020.

BRASIL. Superior Tribunal de Justiça.REsp 883656/RS. Recurso Especial 2006/0145139-9, 09 de março de 2010. Diário da Justiça, DF, 28 fev. 2012. Disponível em: <http://www.stj.jus.br/>. Acesso em: 02 jul. 2020.

BRASIL. Superior Tribunal de Justiça. REsp 1145083/MG. Recurso Especial 2009/0115262-9, 27 de setembro de 2011. Diário da Justiça, DF, 04 set. 2012. Disponível em: < http://www.stj.jus.br/>. Acesso em: 02 jul. 2020.

BRASIL. Superior Tribunal de Justiça. REsp 1114893/MG, Recurso Especial 2008/0243168-8, 16 de março de 2010. Diário da Justiça, DF, 28 fev. 2012. Disponível em: <http://www.stj.jus.br/>. Acesso em: 02 jul. 2020.

BRASIL. Superior Tribunal de Justiça. REsp 1198727/MG. Recurso Especial 2010/0111349-9, 14 de agosto de 2012. Diário da Justiça, DF, 09 mai. 2013. Disponível em: <http://www.stj.jus.br/>. Acesso em: 02 jul. 2020 .

BRASIL. Superior Tribunal de Justiça. REsp 1269494/MG. Recurso Especial 2011/0124011-9, 24 de setembro de 2013. Diário da Justiça, DF, 01 out. 2013. Disponível em: <http://www.sti.jus.br/>. Acesso em: 02 jul. 2020.

BRASIL.Superior Tribunal de Justiça. REsp 1669185/RS. Recurso Especial 2017/0098505-6, 05 de setembro de 2017. Diário da Justiça, DF, 20 out. 2017. Relator: Min. Herman Benjamin. Disponível em: < http:// www.stj.jus.br>. Acesso em: 02 jul. 2020.

BRASIL.Superior Tribunal de Justiça. REsp 1255127/MG. Recurso Especial 2011/0091499-0, 18 de agosto de 2016. Diário da Justiça, DF, 12 set. 2016. Disponível em: < http:/ /www.stj.jus.br>. Acesso em: 02 jul. 2020.

BRASIL. Superior Tribunal de Justiça. REsp 1328753/MG. Recurso Especial 2012/0122623-1, 28 de maio de 2013. Diário da Justiça, DF, 03 fev. 2015. Disponível em: <http://www.stj.jus.br/>. Acesso em: 02 jul. 2020.

BRASIL. Superior Tribunal de Justiça. REsp 1367923/RJ. Recurso Especial 2011/0086453-6, 27 de agosto de 2013. Diário da Justica, DF, 06 set. 2013. Disponível em: < http:/ /www.sti.jus.br>. Acesso em: 02 jul. 2020.

BRASIL. Superior Tribunal de Justiça. REsp 1180078/MG. Recurso Especial 2010/0020912-6, 02 de outubro de 2010. Diário da Justiça, DF, 28 fev. 2012. Disponível em: <http://www.stj.jus.br>. Acesso em: 02 jul. 2020.

BRASIL. Superior Tribunal de Justiça. REsp 883656/RS. Recurso Especial 2006/0145139-9, 09 de março de 2010. Diário da Justiça, DF, 28 fev. 2012. Disponível em: <http://www.stj.jus.br/>. Acesso em: 02 jul. 2020.

BECK, Ulrich. A metamorfose do mundo. Como as alterações climáticas estão transformando a sociedade. Lisboa: Edições 70, 2017.

BOTKIN, Daniel B. Adjusting Law to Nature's Discordant Harmonies. Duke Environmental Law and Policy Forum. v. 7:25. 1996

BOSSELMANN, Klaus. Losing the forest for the trees: environmental reductionism in the Law. Sustainability, 2010. 
BOSSELMANN, Klaus, TAYLOR, Prue. The Significance of the Earth Charter in International Law. The Way Foward, 2009. Disponível em: < https://earthcharter.org/wp-content/assets/virtual-library2/images/uploads/ENG-Bosselmann.pdf > Acesso em: 20 jun. 2020..

BOSSELMANN, Klaus. O princípio da sustentabilidade: transformando direito e governança. São Paulo: Editora Revista dos Tribunais, 2015.

BRUNNEE, Jutta. The Stockholm Declaration and the Structure and Processes of International Environmental Law. In: CHIRCOP, Aldo; MCDORMAN, Ted. (Ed.). The Future of Ocean Regime Building: Essays in Tribute to Douglas M. Johnston. Kluwer, 2008.

BRUCH, Carl. Is International Environmental Law Really Law?: An Analysis of Application in Domestic Courts. Pace Environmental Law Review, n. 23, p. 423-464, 2006.

CAPRA, Fritjof, MATTEI, Ugo. A revolução ecojurídica. O direito sistêmico em sintonia com a natureza e a comunidade. São Paulo: Cultrix, 2018.

CANOTILHO, José Joaquim Gomes. Direito do Ambiente e crítica da razão cínica das normas jurídicas. Revista de Direito do Ambiente e Ordenamento do Território, n. 1, p. 97-99, Set. 1995.

CAPPELLI, Silvia. In dubio pro natura. Revista de Direito Ambiental, v. 98, p. 197-223, abr./jun. 2020.

COELHO, Luiz Fernando. Dogmática, Zetética e Crítica do Direito, Rev. Ciên. Jur. e Soc. da Unipar, v. 11, n. 1, p. 285-310, jan./jun. 2008.

COLÔMBIA. Corte Suprema de Justicia. Radicación 11001-22-03-000-2018-00319-01, 5 de abril de 2018. Victoria Alexandra Arena Sanchez, José Daniel y Felix Jeffry Rodriguez Peña y Otros versus Presidencia de la Republica, Ministerio de Ambinte y Desarollo Sostenible, Ministerio de Agricultura y Desarollo Rural, Unidad Administrativa Especial de Parques Nacionales Naturales, Governaciones de Amazonas, Caquetá, Guainia, Guaviare, Putumayo y Vaupés. Disponível em: < https://observatoriop10.cepal.org/sites/default/ files/documents/stc4360-2018.pdf> Acesso em 18 set. 2020.

COLÔMBIA. Corte Suprema de Justicia. Radicación 1101-22-03-000-2018-00319-01. STC 4360-2018, 5 de abril de 2018. Disponível em: http://www.cortesuprema.gov.co/corte/wp-content/uploads/2018/04/ STC4360-2018-2018-00319-011.pdf. Acesso em: 18 set. 2020.

COLÔMBIA. Corte Constitucional. Sentencia T-622/16, 10 de noviembre de 2016. Consejo Comunitario Mayor de la Organización Popular Campesina del Alto Atrato, Consejo Comunitario Mayor de la Asociación Campesina Integral del Atrato, Asociación de Consejos Comunitarios del Bajo Atrato, Foro Inter-Étnico Solidariedad Chocó y Otros versus Presidencia de la Republica y Otros. Disponível em: < https:/ /www.corteconstitucional.gov.co/relatoria/2016/t-622-16.htm>. Acesso em 20 de jul. 2020.

COLÔMBIA. Supremo Tribunal de Justicia. Radicación 08001-22-13-000-2019-00505-01. STC 3872-2020, 18 de junio de 2020. Luis Miguel Llorente Altamiranda versus Presidencia de la Republica de Colombia, Ministerio de Ambiente y Desarollo Sostenible, La Unidad Administrativa Especial de Parques Nacionales Naturales, la Procuraduría General de la Nación, la Fiscalía General de la Nación, la Policía Nacional y las Corporaciones Autónomas Regionales del Magdalena y Atlantico. Disponível em: < http:// files.harmonywithnatureun.org/uploads/upload953.pdf>. Acesso em: 04 set. 2020.

COLÔMBIA. Tribunal Superior del Distrito Judicial de Ibagué. Radicación 73001-22-00-000-2020-00009100, 28 de agosto de 2020. Juan Felipe versus Presidencia de la Republica, Ministerio de Ambiente y Desarollo Sostenible, Autoridad Nacional de Licencias Nacionales, Ministerio de Minas y Energía, Agencia Nacional de Minería, Ministerio de Transporte, Agencia Nacional de Infraestructura, Unidad de Parques Nacionales Naturales de Colombia, Corporación Autónoma REgional del Tolima-Cortolima, Corporación Autónoma Regional del Quindío, Coporación Autónoma Regional de Risaralda-Carder y Corporación Autónoma Regional de Caldas. Disponível em: <http://files.harmonywithnatureun.org/uploads/upload1017.pdf>. 
Acesso em: 04 set. 2020.

COLÔMBIA. Juzgado 4 deEjecución de Penasy Medidas de Seguridad. Radicación 66001318/004201900057. Sentencia de Tutela 036/2019, 11 de septiembre de 2019. John Edison Parra Sánchez y Jesús Alberto Cardona López versus Ministerio del Medio Ambiente Nacional, Departamento de Risaralda, Municipio de Pereira, Municipio de Dosquebradas, Corporación Autónoma de Risaralda-CARDE y Aguas y Aguas de Pereria. Disponível em: <http://files.harmonywithnatureun.org/uploads/upload949.pdf>. Acesso em: 04 set. 2020.

COLÔMBIA. Tribunal Superior de Medellín. Radicación 050013103004201900071 01. Sentencia 38/2019, 17 de junio de 2019. Juan Luis Castro Córdoba y Diego Hernán David Ochoa versus Ministerio de Ambiente y Desarrollo Sostenible, EPM, Hidroeléctrica Ituango S.A. E.S.P. y otros. Disponível em: <http://files.harmonywithnatureun.org/uploads/upload837.pdf>. Acesso em: 04 set. 2020.

COLÔMBIA. Juzgado Tercero de Ejecución de Penas y Medidas de Seguridad. Acción de Tutela 201900043-00. Sentencia 31/2019, 12 de julio de 2019. Roberto Rodríguez Zamudio versus Corporación Autónoma Regional del Valle del Cauca, Alcaldía Municipal de Cali V., Departamento Administrativo de Gestión del Medio Ambiente, Departamento Administrativo de Planeación Municipal, Empresas Municipales de Cali V., EICE ESP, las administraciones de los proyectos urbanísticos o conjuntos residenciales o condominios campestres "Reservas de Pance" y "Altos de Pance" y "JARAMILLO MORA S.A.”. Disponível em: <http:// files.harmonywithnatureun.org/uploads/upload948.pdf>. Acesso em: 04 set. 2020.

COLÔMBIA. Supremo Tribunal Administrativo de Boyacá. Radicación 152383333002201800016 01, 29 de junio de 2018. Juan Carlos Alvarado Rodríguez y otros versus Ministerio de Medio Ambiente y otros. Disponível em: < http://files.harmonywithnatureun.org/uploads/upload731.pdf>. Acesso em: 04 set. 2020.

COLÔMBIA. Juzgado Primero Penal del Circuito con Funciones de Conocimiento - Neiva - Huila. Radicación 41001-3109-001-2019-00066-00. Sentencia de Tutela 71/2019, 24 de octubre de 2019. Andres Felipe Rojas Rodriguez y Daniel Leandro Sanz Perdomo versus Ministerio del Ambiente y Desarollo Sostenible, Autoridad Nacional de Licencias Ambientales-ANLA, Gobernacion del Huila, Aguas del Huila, Cooperación Autónoma Regional del Alto Magdalena-CAM, Empresas Publicas de Neiva, Municipios de Neiva, San Augustin, Pitalito, Saladoblanco, Oporapa, Altamira, Guadalupe, Hobo, Yagura, Aipe, Villavieja, Gigante Garzon, Paicol, Tesalia y Palermo. Disponível em: < http:/ files.harmonywithnatureun.org/uploads/ upload869.pdf>. Acesso em: 04 set. 2020.

COLÔMBIA. Tribunal Administrativo de Quindío. Radicación 63001--000-2019-00024-00, 05 de diciembre de 2019. Carlos Alberto Arrieta Martínez, Luisa Fernanda León Betancourth y Juliana Victoria Ríos Quintero versus Nación-Ministerio de Vivienda, Ciudad y Territorio -, Corporación Autónoma Regional de Quindío, Municipio de Armenia, Empresas Publicas de Armenia, Municipio de Salento, Empresas Publicas del Quindío - E.P.Q, Asociación de los Suscriptores del Acueducto Rural El Rosario de la Vereda Boquía del Municipio de Salento. Disponível em: <http://files.harmonywithnatureun.org/uploads/upload997.pdf>. Acesso em: 04 set. 2020.

COLÔMBIA. Juzgado Único Civil Municipal - La Plata - Huila. 41-396-40-03-001-2019-00114-00, 19 de marzo de 2019. Luz Marina Díaz y Otros habitantes del Barrio El Remolino de La Plata - Huila versus Empresa de Servicios Públicos del Municipio de La Plata - Huila -"EMSERPLA E.S.P.". Disponível em: <http://files.harmonywithnatureun.org/uploads/upload823.pdf>. Acesso em: 04 set. 2020.

COLÔMBIA. Tribunal Administrativo de Tolima. Radicación 73001-23-00-000-2011-00611-00, 30 de mayo de 2019. Personería Municipal de Ibagué versus Ministerio de Medio Ambiente y otros. Disponível em: <http:// files.harmonywithnatureun.org/uploads/upload836.pdf>. Acesso em: 04 set. 2020.

COLÔMBIA. Corte Suprema de Justicia. Radicación 17001-22-13-000-2017-00468-02. AHC4806-2017, 26 de julio de 217. Disponível em: <http:/ /www.cortesuprema.gov.co/corte/wp-content/uploads/relatorias/ 
tutelas/B\%20SEP2017/AHC4806-2017.doc>. Acesso em 18 set. 2020.

CONVENTION ON BIOLOGICAL DIVERSITY. Aichi Biodiversity Targets. Disponível em: < https:// www.cbd.int/sp/targets/>. Acesso em 15 jul. 2020.

COSTA RICA. Corte Interamericana de Derechos Humanos. Opinion consultiva OC-23/17, de 15 de noviembre de 2017. Disponível em: <http://www.corteidh.or.cr/docs/opiniones/seriea_23_esp.pdf>. Acesso em: 02 set. 2020.

COSTA RICA. Corte Interamericana de Derechos Humanos. "Caso comunidades indígenas miembros

de la asociación Lhaka Honhat (nuestra tierra) versus Argentina" (fondo, reparaciones y costas), sentencia 6 de febrero de 2020. Disponível em: < https://www.corteidh.or.cr/docs/casos/articulos/seriec_400_esp. pdf>. Acesso em: 04 set. 2020.

CRUTZEN, Paul; STEFFEN, Will; MACNEILL, John. The Anthropocene: Are Humans Now Overwhelming the Great Forces of Nature? Ambio, v. 36, n. 8, p. 613-621, Dec. 2007.

CRUTZEN, Paul. Human Impact On Climate Has Made This the "Anthropocene Age". New Perspectivies Quartely, v. 22, n. 2, p. 14-16, Mar. 2015.

CRUTZEN, Paul. STEFFEN, Will; MACNEILL, John; GRINEVALD, Jacques. The Anthropocene: conceptual and Hisorical Perspectives. Philosofical Transactions of the Royal Society, v. 369, p. 842-867, 2011.

DELMAS-MARTY, Mireille. Por um direito comum. São Paulo: Martins Fontes, 2004.

ECUADOR. Assamblaya Constituyente. Constitución del Ecuador. Disponível em: < https://www.oas.org/ juridico/mla/sp/ecu/sp_ecu-int-text-const.pdf>. Acesso em: 04 set. 2020.

El Espectador. El histórico fallo para proteger la babía de Cartagena. 2020. Disponível em: <https://www.elespectador.com/noticias/judicial/el-historico-fallo-para-proteger-la-bahia-de-cartagena/>. Acesso em: 04 set. 2020.

EUROPE. European Comission. COMMUNICATION FROM THE COMMISSION TO THE EUROPEAN PARLIAMENT, THE EUROPEAN COUNCIL, THE COUNCIL, THE EUROPEAN ECONOMIC AND SOCIAL COMMITTEE AND THE COMMITTEE OF THE REGIONS. The European Green Deal <Disponível em: https://ec.europa.eu/info/sites/info/files/european-green-deal-communication_en.pdf>. Acesso em: 14 jul. 2020.

GARGARELLA, Roberto. Explicando o constitucionalismo latino-americano. Journal of the Max Planck for European Legal History, n. 24, 2014.

HAMILTON, Clive. Defiant Earth. The fate of humans in the anthropocene. Cambridge: Polity, 2017.

JAYME, Erik. Jayme, Erik, Identité culturelle et intégration : le droit international privé postmoderne. In: Collected Courses of the Hague Academy of International Law. Leiden: Martinus Nijhoff, 1995.

KIM, Rakhyun E.; BOSSELMANN, Klaus. International Environmental Law in the Anthropocene: Towards a Purposive System of Multilateral Environmental Agreements. Transnational Environmental Law, v. 2, issue 02, 2013.

KLEIN, Naomi. The (Burning)Case for a Green New Deal. New York: Simon \& Schuster. 2019.

LADEUR, Karl-Heinz. A relação entre direito público e normas sociais no constitucionalismo - nacional, europeu e global. Direito UnB, v. 2, p. 17, jan./abr. 2016.

LAITOS, Jan. Why Environmental Policies Fail. Cambridge: Cambridge University Press. 2017.

KOTZÉ, Louis J. Global Environmental Constitutionalism in the Anthropocene. Oxford: Hart Publishing, 2016.

LATOUR, Bruno. Facing Gaia. Eight Lecture on the New Climatic Regime. London: Polity, 2017. 
LATOUR, Bruno. LENTON, Timothy M. Extending the Domain of Freedom, or Why Gaia Is So Hard to Understand. Critical Inquiry, v. 45, n. 3. Springer 2019.

LEITE, José Rubens Morato; VENÂNCIO, Marina Demaria. Environmental Protection in Brazil's High Court: safeguarding the environment through a Rule of Law for Nature, Sequência, n. 77, p. 29-50, nov. 2017.

LEITE, José Rubens Morato; AYALA, Patryck de Araujo; CAPDEVILLE, Fernanda Cavedon; MELO, Melissa Ely; SILVEIRA, Paula Galbiatti; DAROS, Leatrice Faraco. A Ecologização do Direito Ambiental Vigente. Rupturas Necessárias. Rio de Janeiro: Lumen Juris, 2018.

LEITE, José Rubens Morato; GALBIATTI, Paula. A Ecologização do Estado de Direito: uma Ruptura ao Direito Ambiental e ao Antropocentrismo Vigentes. In. LEITE, José Rubens Morato; AYALA, Patryck de Araujo; CAPDEVILLE, Fernanda Cavedon; MELO, Melissa Ely; SILVEIRA, Paula Galbiatti; DAROS, Leatrice Faraco. A Ecologização do Direito Ambiental Vigente. Rupturas Necessárias. Rio de Janeiro: Lumen Juris, 2018.

LENTON, Timothy M.; HELD, Hermann; KRIEGLER, Elmar Et. al. Tipping elements in the Earth's climate system. PNAS, 2008. Disponível em: <https://www.pnas.org/content/105/6/1786> Acesso em: 30 out. 2020.

MARGALIT, Avishai. La sociedad decente. Barcelona: Paidos, 1997.

MEXICO. Suprema Corte de Justicia de la Nación. Amparo en Revisión 307/2016, , Sentencia de 14 de noviembre de 2018. Disponível em: < https://www.scjn.gob.mx/sites/default/files/listas/documento_ dos/2018-11/AR-307-2016-181107.pdf >. Acesso em: 10 set. 2020.

MORIN, Edgar. Fraternidade. Para resistir à crueldade do mundo. São Paulo: Palas Atenas, 2019.

MORIN, Edgar; KERN, Anne Brigitte. Terra-Pátria. Porto Alegre: Sulina, 2011.

NOBRE, Carlos; LOVEJOY, James. Amazon Tipping Point. Science Advances, Issue 4, p. 1, Feb. 2018.

NOBRE, Carlos; LOVEJOY, James. Amazon tipping point: Last chance for action. Science Advances, Issue 5, p. 1-2, Dec. 2019.

PELLUCHON, Corine. Réparons le monde. Humains, animaux, nature. Paris: Payot \& Rivage, 2020.

PELLUCHON, Corine. El coronavirus nos muestra vulnerables, pero puede traer una toma de conciencia. 2020. Disponível em: <https://www.clarin.com/revista-enie/ideas/corine-pelluchon-coronavirus-muestra-vulnerables-puede-traer-toma-conciencia-_0_h5o9qiPvD.html > Acesso em: 15 jul. 2020.

ROCKSTROM, Johan; STEFFEN, Will, NOONE, Kevin. Planetary boundaries: exploring the Safe Operating System for Humanity. Ecology and Society. v. 14. 2009. Disponível em: < https://www.jstor.org/ stable/26268316?seq=2\#metadata_info_tab_contents $>$ Acesso em: 21 set. 2020.

ROCKSTROM, Johan; STEFFEN, Will; NOONE, Kevin. A safe operating space for humanity. Nature. v. 461/24, 2009. Disponível em: <https://www.nature.com/articles/461472a> Acesso em: 20 set. 2020.

PEREZ, Oren. Ecological Sensitivity and Global Legal Pluralism: Rethinking the Trade and Environment Conflict. Oxford: Hart Publishing, 2004.

PLANETARY EMERGENCY PLAN: Securing a New Deal for People, Nature and Climate. Switzerland: The Clube of Rome, 2019. PLANETARY EMERGENCY 2.0: Securing a New Deal for People, Nature and Climate. Switzerland: The Clube of Rome, 2020.

ROBINSON, Nicholas A.; WALZER, Christian. How Do We Prevent the Next Outbreak? Our planning needs to take account of the complex interconnections among species, ecosystems and human society. Disponível em: < https://blogs.scientificamerican.com/observations/how-do-we-prevent-the-next-outbreak/>. Acesso em: 15 set. 2020. 
RUTZ, Christian et al. COVID-19 lockdown allows researchers to quantify the effects of human activity on wildlife . Nature Ecology \& Evolution, v. 4, p. 1156-1159, sept. 2020.

SARLET, Ingo Wolfgang; FENSTERSEIFER, Tiago. Curso de Direito Ambiental Brasileiro. Rio de Janeiro: Forense, 2020.

SARLET, Ingo Wolfgang; FENSTERSEIFER, Tiago. Direito constitucional ecológico: constituição, direitos fundamentais e proteção da natureza. 6. ed. São Paulo: Thomson Reuters Brasil, 2019.

SHELTON, Dinah. Introduction. Legal Systems: Incorporation, Transformation and Persuasion. Oxford: Oxford University Press, 2011. p. 1-22.

SHELTON, Dinah. Soft Law. Disponível em: https://ssrn.com/abstract=1003387. Acesso em: 20 mai. 2019.

SOZZO, Gonzalo. Derecho Privado Ambiental. El Giro Ecológico del Derecho Privado. Santa Fe: Rubinzal-Culzoni, 2019.

STEFFEN, Will; RICHARDSON, Katherine; ROCKSTROM, Johan; Et al. Planetary boundaries: Guiding buman development on a changing planet. Science, . 347. 2015. Disponível em: < https:// science.sciencemag.org/ content/347/6223/1259855> Acesso em: 21 set. 2020.

STENGERS, Isabelle et al. Restituing Nature: A Latourian Workshop. Environmental Humanities, v. 6, p.169, 2015.

SOUSA SANTOS, Boaventura de. A Cruel Pedagogia do Virus. Coimbra: Almedina, 20020.

SUNSTEIN, Cass; THALER, Richard. Nudge: Improving Decisions about Health, Wealth and Happiness. Yale University Press, 2008.

TEUBNER, Gunter. Fragmentos constitucionais. Constitucionalismo social na globalização. Trad. de: Marcelo Neves, Pedro Ribeiro, Ricardo Campo, Rodrigo Mendes. São Paulo: Saraiva, 2016.

TOLEFFSON, Jeff. Why Deforestation and Extinctions make Pandemics More Likely. Nature, v. 584, p. 175-16, aug. 2020.

UNESCO. The Earth Charter. Disponível em: < http://www.unesco.org/education/tlsf/mods/theme_a/ img/02_earthcharter.pdf> Acesso em: 29 jun. 20.

UNITED NATIONS. General Assembly. Report of the Special Rapporteur on the issue of human rights obligations relating to the enjoyment of a safe, clean, healthy and sustainable environment, David R. Boyd. Human rights depend on a healthy biosphere. Disponível em: <https://undocs.org/A/75/161> Acesso em: 10 set. 2020 .

UNITED NATIONS. Rio Declaration on Environment and Development. Disponível em: <https://www. un.org/en/development/desa/population/migration/generalassembly/docs/globalcompact/A_ CONF.151_26_V.I_Declaration.pdf>. Acesso em: 12 jul. 2020.

UNITED NATIONS ENVIRONMENTAL PROGRAMME. Convention on Biological Diversity. Global Biodiversity Outlook 5. Disponível em: <https://www.cbd.int/gbo5>. Acesso em: 20 set. 2020.

UNITED NATIONS ENVIRONMENTAL PROGRAMME. Environmental Rule of Law. First Global Report. 2019. Disponível em: <https://www.unenvironment.org/resources/assessment/environmental-rule-law-first-global-report> Acesso em: 15 jul. 2020.

WEISS, Edith Brown. Rule of law for nature in a kaleidoscopic world. In: VOIGT, Christina (Ed.). Rule of Law for Nature: New dimensions and Ideas in Environmental Law. Cambridge: Cambridge University Press, 2013 
WESTRA, Laura. The Ethics of Integrity and the Law in Global Governance. University of California, Davis, v. 37:127

WORLD HEALTH ORGANIZATION. Zoonotic disease: emerging public health threats in the Region. Disponível em: <http://www.emro.who.int/fr/about-who/rc61/zoonotic-diseases.html>. Acesso: 15 jul. 2020. 
Para publicar na revista Brasileira de Políticas Públicas, acesse o endereço eletrônico www.rbpp.uniceub.br

Observe as normas de publicação, para facilitar e agilizar o trabalho de edição. 